\title{
CONSEQUENCES OF EXERCISING THE PRIVILEGE AGAINST SELF-INCRIMINATION
}

\author{
LEONARD G. RATNER* \\ 7 PEE PRIVILEGE against self-incrimination, embodied in the Fifth \\ Amendment to the Constitution of the United States ${ }^{1}$ and in the con- \\ stitutions of all but one of the states, ${ }^{2}$ protects a witness who proper- \\ ly claims it from being compelled to answer incriminating questions ${ }^{3}$ and per- \\ mits a defendant in a criminal case to refrain from giving any testimony. 4 \\ The privilege is usually asserted by a witness in response to a question which \\ either asks him directly whether he has committed a specified crime or asks \\ him about evidentiary facts that may implicate him in the commission of a \\ crime. ${ }^{5}$ It is not yet settled whether an adverse inference may reasonably be \\ drawn concerning the prior conduct of a person who validly asserts the privi- \\ lege, and whether he may be discharged from public employment for exercis- \\ ing this constitutional right.
}

\section{Inferences from Assertion of the Privitegee}

Since an innocent person may be enmeshed in suspicious circumstances which, if revealed, would tend to connect him with a crime he did not commit, Law.

* Member of the California Bar; Lecturer, University of Southern California School of

1 "Nor shall any person . . . be compelled in any criminal case to be a witness against himself."

${ }^{2}$ Forty-six states have constitutional provisions which expressly protect persons from being compelled to give evidence against themselves in criminal matters. Consult 8 Wigmore, Evidence 320-24 (3d ed., 1940). In Iowa there is no express constitutional provision to this effect but the supreme court of that state has held that the self-incrimination privilege is included in the due process clause of the state constitution. State v. Height, 117 Iowa 650 , 91 N.W. 935 (1902) ; Koenck v. Cooney, 244 Iowa 153, 55 N.W.2d 269 (1952). Consult McGovney, Self-Criminating and Self-Disgracing Testimony, 5 Iowa L. Bull. 174, 179 (1920); 8 Wigmore, Evidence 320 (3d ed., 1940). Cf. Twining v. New Jersey, 211 U.S. 78 (1908), and Adamson v. California, 332 U.S. 46 (1947), holding the self-incrimination privilege is not included in the Due Process Clause of the Fourteenth Amendment to the Federal Constitution, but see, to the contrary, Adamson v. California, 332 U.S. 46, 68, 124 (1947) (dissents) ; Feldman v. United States, 322 U.S. 487, 494 (1944) (dissent) ; Regan v. New York, 349 U.S. 58, 65, 66 (1955) (concurrence and dissent). In New Jersey the self-incrimination privilege is not constitutionally guaranteed but is enforced as a part of the common law. State v. Zdanowicz, 69 N.J.L. 619, 55 Atl. 743 (1903) ; State v. Miller, 71 N.J.L. 527, 60 Atl. 202 (1905).

${ }^{3}$ Hoffman v. United States, 341 U.S. 479 (1951) ; Arndstein v. McCarthy, 254 U.S. 71, 72 (1920); Counselman v. Hitchcock, 142 U.S. 547, 562 (1892).

- Consult 8 Wigmore, Evidence 392 (3d ed., 1940).

'Maffie v. United States, 209 F.2d 225, 228 (C.A. 1st, 1954). 
the assertion of the privilege in response to a question concerning possibly incriminating evidentiary facts should give rise to no inference that the witness is guilty of a crime. ${ }^{6}$ Thus, a person who was present at the commission of a crime may validly refuse to answer questions concerning his whereabouts when the crime was committed, and from this refusal to answer no inference should be drawn that he committed the crime. Possibly an inference should be drawn, however, that his answer would have revealed some fact tending to implicate him in the crime.

The "suspicious circumstances" rationale does not so clearly apply to questions which ask directly whether a certain crime has been committed. If the witness is innocent of the crime, a denial of its commission will reveal no circumstances tending to connect him with it. ${ }^{7}$ The assertion of the privilege in response to such a question, therefore, might justify an inference that the witness did commit the crime.

Nevertheless, the principle is well established that the valid assertion by a person of the privilege against self-incrimination will not, in any criminal action against him, give rise to an inference that he is guilty of a crime or of acts tending to connect him with a crime. ${ }^{8}$ This rule is compelled by the nature of the privilege. If a person is constitutionally protected from being forced to give testimony which may be used against him in a prosecution for crime, such protection would be illusory if the very act of asserting the privilege constituted an admission of incriminating facts which could be used as evidence against him in a criminal case. ${ }^{9}$

A few states allow the judge or prosecutor in a criminal case to comment to the jury upon the failure of a non-testifying defendant to explain or deny evidence tending to establish his guilt. ${ }^{10}$ This right of comment in effect permits

- Ullman v. United States, 350 U.S. 422, 426-28 (1956) ; Maffie v. United States, 209 F.2d 225, 227-29 (C.A. 1st, 1954); United States v. Shaughnessy, 212 F.2d 128, 129 (C.A. 2d, 1954); Healey v. United States, 186 F.2d 164, 167 (C.A. 9th, 1950). Consult Griswold, The Fifth Amendment Today 9, 56-57 (1955).

${ }^{7}$ By a non-incriminating answer a witness, other than a defendant in a criminal case, does not waive the right to assert the privilege as to further questions of an incriminating nature. Rogers v. United States, 340 U.S. 367, 373-74 (1951); McCarthy v. Arndstein, 262 U.S. 355, 359 (1923) ; Arndstein v. McCarthy, 254 U.S. 71 (1920); United States v. St. Pierre, 128 F.2d 979 (C.A. 2d, 1942). Consult note 44 infra. An affirmative or an expository answer might constitute such a waiver, but a denial clearly would not.

' Ullman v. United States, 350 U.S. 422, 426-28 (1956) ; Noto v. United States, 76 S.Ct. 265 (1955) ; Burdick v. United States, 236 U.S. 79 (1915); Maffie v. United States, 209 F.2d 225, 228 (C.A. 1st, 1954); United States v. Shaughnessy, 212 F.2d 128 (C.A. 2d, 1954) ; Spector v. United States, 193 F.2d 1002 (C.A. 9th, 1952); Healey v. United States, 186 F.2d 164 (C.A. 9th, 1950). Consult 8 Wigmore, Evidence 412 (3d ed., 1940), and cases there cited.

${ }^{9}$ Maffie v. United States, 209 F.2d 225, 228 (C.A. 1st, 1954). See People v. Tyler, 36 Cal. $522(1869)$.

${ }^{20}$ New Jersey, Ohio, Vermont, Connecticut, Iowa and California permit such comment. See cases and statutes collected in 8 Wigmore, Evidence 412-15 n. 2, and supp. (3d ed., 1940). See Adamson v. California, 332 U.S. 46, 55 (1947). In California and Ohio such comment 
an adverse inference to be drawn from the defendant's failure to come forward with evidence within his power to produce. ${ }^{11}$ Although the failure results from his exercise of the self-incrimination privilege, the inference arises, not from the exercise of the privilege, but from the presence in the record of unrefuted, adverse evidence. ${ }^{12}$ In the absence of such independent, adverse evidence no inference may be drawn from a refusal to testify by a defendant in a criminal case, nor may such an inference be used against the defendant by the prosecution in lieu of affirmative proof of guilt. ${ }^{13}$ Most jurisdictions refuse to permit such comment because the threat of comment, if the defendant fails to explain or deny adverse evidence, constitutes a form of compulsion upon him to testify, thereby weakening the extent of the protection afforded by the privilege. ${ }^{14}$

was authorized by constitutional amendments which had the effect of modifying the scope of the existing constitutional provisions setting forth the privilege. People v. Adamson, 27 Cal.2d 478, 165 P.2d 3 (1946); Leonard v. State, 100 Ohio St. 456, 472, 127 N.E. 464, 468 (1919).

${ }^{11}$ People v. Adamson, 27 Cal.2d 478, 488-91, 165 P.2d 3, 8-10 (1946) ; Adamson v. California, 332 U.S. $46,55-56$ (1947).

${ }^{12}$ State v. Edelman, 19 N.J.Super. 350, 88 A.2d 516 (1952); State v. Levine, 117 Vt. 320, 91 A.2d 678 (1952); State v. Nelson, 139 Conn. 124, 90 A.2d 157 (1952); City of Cincinnati v. Levine, 81 Ohio App. 181, 75 N.E.2d 177 (1947) ; People v. Adamson, 27 Cal.2d 478, 488-91, 165 P.2d 3, 8-10 (1946); State v. Ferguson, 226 lowa 361, 283 N.W. 917 (1939). Consult Griswold, op. cit. supra note 6, at 21-22. If the defendant elects to testify in his own defense, he waives the privilege and must answer all pertinent questions even though the answers may be incriminating. His failure to explain or deny unfavorable evidence while thus testifying will give rise to an adverse inference. 8 Wigmore, Evidence 433-34, 440 et seq. (3d ed., 1940).

${ }^{13}$ Cases cited note 12 supra. See People v. Talle, 111 Cal.App.2d 650, 245 P.2d 633 (1952) ; People v. Sanchez, 35 Cal.2d 522, 219 P.2d 9 (1950) ; Bruce, The Right To Comment on the Failure of the Defendant To Testify, 31 Mich. L. Rev. 226, 229, 231 (1932); 2 Wigmore, Evidence 179 (3d ed., 1940); Dunmore, Inference from Claim of Privilege by Accused, 3 J. Crim. L. \& Criminology 770, 774 (1913).

${ }^{14}$ People v. Adamson, 27 Cal.2d 478, 487, 165 P.2d 3, 8 (1946); Dunmore, Comment on Failure of Accused To Testify, 26 Yale L. J. 464, 466 (1917); 8 Wigmore, Evidence 412 (3d ed., 1940) ; Reeder, Comment upon Failure of Accused To Testify, 31 Mich. L. Rev. 40 (1932).

Several cases in jurisdictions which follow the majority rule, including a United States Supreme Court decision, have held that if a defendant in a criminal case waives the privilege by electing to testify, he may be impeached by evidence that he had previously asserted the privilege, with regard to matters covered by his testimony, either at a former trial, a grand jury proceeding or a preliminary investigation, and that an adverse inference may be drawn in the current trial from his failure to contradict unfavorable evidence at the time of such previous assertion of the privilege. Raffel v. United States, 271 U.S. 494 (1926), and cases collected in 8 Wigmore, Evidence 434, n. 8, and supp. (3d ed., 1940). Contra: Parrott v. State, 125 Tenn. 1, 139 S.W. 1056 (1911); Wilson v. State, 54 Tex.Crim. 505, 113 S.W. 529 (1908); Smith v. State, 90 Miss. 111, 43 So. 465 (1907) ; State v. Bailey, 54 Iowa 414,6 N.W. 589 (1880). These cases appear to be inconsistent with the majority rule. They also appear basically inconsistent with the general rule that if an accused waives the 
Many commentators, including Wigmore, are of the opinion, however, that apart from criminal proceedings there are circumstances under which an adverse inference concerning the conduct of a person who has previously invoked the privilege may be justified..$^{15}$ They assert that a witness who has refused to answer a question on the ground of self-incrimination must have done so because his answer would have either admitted the commission of a crime, furnished evidence tending to connect him with a crime, furnished clues to such evidence, or led to the eliciting of such evidence by further questions. They therefore conclude that logic compels an inference that the potential

privilege by testifying at a grand jury proceeding, preliminary hearing or investigation, or at his first trial, he is not precluded from asserting the privilege at a subsequent trial. See cases collected at 8 Wigmore, Evidence $450-51$ (3d ed., 1940).

If a constitutional provision guarantees that a defendant in a criminal case may exercise the privilege without an inference resulting from his failure to contradict adverse evidence, it is difficult to see why his decision at a later time to testify fully concerning the matter should justify retroactively the drawing of an adverse inference from the previously valid exercise of the privilege. The decision of a defendant to testify should constitute a waiver of the privilege only as to the testimony given at that time. To effect a retroactive waiver the defendant would have to be returned to the time and place of the initial assertion of the privilege and be given an opportunity to testify in light of his waiver. If, in lieu of this manifest impossibility, the defendant asserts that his testimony at that time would have been the same as his current testimony, there remains neither an inconsistent statement nor a failure to contradict adverse evidence and therefore no grounds for impeachment or for drawing an unfavorable inference.

If a person under suspicion is called to testify before a grand jury or at a preliminary hearing or investigation, surely be should be able to exercise the privilege without creating a trap for himself in the event that he later decides to testify at the trial. See Hall Motor Freight v. Montgomery, 357 Mo. 1188, 212 S.W.2d 748 (1948); Masterson v. St. Louis Transit Co., 204 Mo. 507, 103 S.W. 48 (1907); State v. Bailey, 54 Iowa 414, 6 N.W. 589 (1880). When a person validly exercises the privilege, he is entitled to the full protection that the privilege affords. See Johnson v. United States, 318 U.S. 189, 196-99 (1943), including protection from adverse inferences. It is no answer to say that by waiving the privilege at a later time a defendant opens himself to full cross-examination on the same basis as any witness, because no witness should be subjected to impeachment on the basis of a retroactive waiver of the privilege.

If the privilege was previously asserted by a defendant in a jurisdiction permitting an adverse inference from the resulting failure to contradict unfavorable evidence, perhaps the same inference should be available for evidentiary and/or impeachment purposes in a later hearing wherein he elects to testify, because no retroactive waiver is then involved. If the inference which arises from a failure to contradict adverse evidence is confined to the particular hearing wherein the privilege is exercised, however, the inference would have no application in any other hearing, even a second trial in the same case. In that event any such inference in the subsequent hearing would have to arise from the failure of the defendant to contradict adverse evidence in that hearing.

${ }^{{ }^{15}} 8$ Wigmore, Evidence 419 et seq. (3d ed., 1940); Noonan, Inferences from the Invocation of the Privilege against Self-Incrimination, 41 Va. L. Rev. 311 (1955); Williams, Problems of the Fifth Amendment, 24 Fordham L. Rev. 19 (1955) ; Loss of Employment by Asserting the Privilege against Self-Incrimination: A Professor's Dilemma, 34 Neb. L. Rev. 88 (1954) ; Meltzer, The Privilege against Self-Incrimination, New Republic (Mar. 1-, 1955) 18. Consult Griswold, op. cit. supra note 6, at 56-57; Maffie v. United States, 209 F.2d 225, 228-29 (C.A. 1st, 1954); Sheiner v. State, 82 So.2d 657, 662 (Fla., 1955). 
answer would have been incriminating; otherwise the witness had no right to assert the privilege. If this analysis is correct, the assertion of the privilege, in effect, constitutes an implied admission that the witness has committed either a crime or acts tending to connect him with a crime.

Such an admission could not be used as evidence against the witness in criminal proceedings for the reasons previously stated. An inference that a crime, or some of the elements of a crime, had been committed would, however, tend to support the discharge of public employees for invoking the privilege and to substantiate the conclusions adverse to persons asserting the privilege drawn by legislators, newspapers and laymen. It is therefore necessary to determine whether in a non-criminal proceeding an adverse inference should be drawn from a prior assertion of the privilege.

A number of cases have permitted an adverse inference to be drawn against a party to a civil action who has exercised the privilege during the trial of that action. ${ }^{16}$ Despite broad language linking it with the exercise of the privilege, however, the inference in these cases, as in those criminal cases permitting comment, actually arises not from the assertion of the privilege but from the silence of the party in the face of other uncontradicted, adverse evidence. ${ }^{17}$

Unlike a defendant in a criminal case, a party to a civil action must testify if called as a witness, even though his answers may constitute evidence adverse to him in that action. ${ }^{18}$ As a witness he has the same right as any other witness to assert the privilege when questioned on incriminating matters. ${ }^{19}$ But as a party to the action he must refute evidence contrary to his position in order to win the judgment. If he fails to come forward with evidence within his power to produce, it will be presumed unfavorable to him, ${ }^{20}$ and if he fails to counter adverse evidence introduced by the opposing party, the trier of fact

\footnotetext{
${ }^{16}$ United States v. Mammoth Oil Co., 14 F.2d 705, 729 (C.A. 8th, 1926), aff'd 275 U.S. 13, 52-53 (1927) ; Stillman Pond, Inc. v. Watson, 115 Cal.App.2d 440, 443-44, 252 P.2d 717, 718 (1953) ; Ikeda v. Curtis, 43 Wash.2d 449, 261 P.2d 684 (1953); Fross v. Wotten, 3 Cal.2d 384, 393-95, 44 P.2d 350, 354-55 (1935); Morris v. McClellan, 154 Ala. 639, 45 So. 641 (1908); Morgan v. Kendall, 124 Ind. 454, 24 N.E. 143 (1890). See In re Fenn, 235 Mo.App. 24, 128 S.W.2d 657 (1939) ; Fish v. State Bar of California, 214 Cal. 215, 4 P.2d 937 (1931); In re Vaughan, 189 Cal. 491, 209 Pac. 353 (1922); In re Wellcome, 23 Mont. 450,59 P.2d 445 (1899). Cf. United States ex rel. Vajtauer v. Comm'r of Immigration, 273 U.S. 103, 112 (1927) ; Bilokumsky v. Tod, 263 U.S. 149, 153-54 (1923) ; Carne v. Litchfield, 2 Mich. 340 (1852). See also United States ex rel. Zapp v. Dist. Dir. of Immigration, 120 F.2d 762 (C.A. 2d, 1941), which appears to misconstrue the Vajtauer case, supra.

${ }^{17}$ See Sheiner v. State, 82 So.2d 657, 665 (Fla., 1955); cf. Noonan, op. cit. supra note 15, at 332 ; Williams, op. cit. supra note 15 , at $41-42$; Neb. L. Rev., op. cit. supra note 15 , at 91 .

${ }^{28} 8$ Wigmore, Evidence 176-77, 327 (3d ed., 1940). Consult Applicability of Privilege against Self-Incrimination to Legislative Investigations, 49 Col. L. Rev. 87 (1949).

${ }^{18}$ McCarthy v. Arndstein, 262 U.S. 355 (1923) ; McCarthy v. Arndstein, 266 U.S. 34 (1924); Boyd v. United States, 116 U.S. 616 (1886).

${ }^{20}$ Consult 2 Wigmore, Evidence 162́, 176, 179 (3d ed., 1940).
} 
may accept such evidence and the inferences arising therefrom as true in reaching a decision in the case. ${ }^{21}$

Therefore, if evidence is introduced in a civil action tending to indicate that one of the parties has been guilty of a criminal act, and that party, by exercising his self-incrimination privilege as a witness, refuses to refute or deny such evidence, the court or jury may infer that the adverse evidence and its implications are true, ${ }^{22}$ but it is the failure to contradict the adverse evidence, not the exercise of the privilege, that produces the inference. There appears to be no case upholding a judgment against a party solely on the basis of an inference resulting from his exercise of the privilege at the trial in the absence of independent, adverse evidence. ${ }^{23}$

The obligation to refute or deny adverse evidence, moreover, applies only to a party to an action, not to a witness. The assertion of the privilege by a witness, whether testifying before a court, grand jury, committee or investigative agency, does not give rise to an inference adverse to him in any civil action to which he may thereafter become a party. ${ }^{24}$ Almost all the cases which have considered the issue also hold that a witness in a civil action may not be impeached by evidence that he had previously asserted the privilege with regard to matters covered by his testimony. ${ }^{25}$

21 United States ex rel. Vajtauer v. Comm'r of Immigration, 273 U.S. 103 (1927); One 1941 Ford v. United States, 140 F.2d 255 (C.A. 6th, 1944); United States v. Mammoth Oil Co., 14 F.2d 705, 729 (C.A. 8th, 1926), aff'd 275 U.S. 13, 52-53 (1927); Att'y General v. Pelletier, 240 Mass. 264, 316, 134 N.E. 407, 423 (1922) ; Warren v. Holbrook, 95 Mich. 185, 191, 54 N.W. 712, 713 (1893).

$\simeq$ Cases cited at note 16 supra.

${ }^{2}$ See Sheiner v. State, 82 So.2d 657 (Fla., 1955) (quoted note 174 infra), indicating that an inference of improper conduct based solely on an exercise of the self-incrimination privilege is, in the absence of any other evidence in support thereof, a violation of due process of law. See also Slochower v. Board of Higher Education of New York City, 350 U.S. 551 (1956). If the party asserting the privilege has the burden of proof or of going forward with evidence on an issue, the finding will, of course, be against him on that issue if there is no evidence at all relating thereto.

" Hall Motor Freight v. Montgomery, 357 Mo. 1188, 212 S.W.2d 748 (1948); Loewenherz v. Merchants and Mechanics Bank, 144 Ga. 556, 87 S.W. 778 (1916). See Masterson v. St. Louis Transit Co., 204 Mo. 507, 103 S.W. 48 (1907).

${ }^{25}$ Hall Motor Freight v. Montgomery, 357 Mo. 1188, 212 S.W.2d 748 (1948); Barnhart v. Martin, 327 Ill.App. 551, 64 N.E.2d 748 (1945); Fries v. Berberich, 177 S.W.2d 640 (Mo.App., 1944) ; Loewenherz v. Merchants and Mechanics Bank, 144 Ga. 556, 87 S.E. 778 (1916); Masterson v. Transit Co., 204 Mo. 507, 103 S.W. 48 (1907) ; Right To Show in Civil Case that Party or Witness Refused To Testify on Same Matter under Claim of Privilege in Previous Criminal Proceeding, 2 A.L.R.2d 1297 (1948). See Garrett v. St. Louis Transit Co., 219 Mo. 65, 118 S.W. 68 (1909) ; Hill v. Missouri Packing Co., 24 S.W.2d 196 (Mo.App., 1930). Cf. Harrison v. St. Louis-San Francisco Ry. Co., 291 S.W. 525 (Mo.App., 1927). Contra: Childs v. Merrill, 66 Vt. 302, 29 Atl. 532 (1894). Compare the cases in note 14 supra, holding that a defendant in a criminal action who waives the privilege by electing to testify may be impeached by evidence that he had previously asserted the privilege with regard to matters covered by his testimony, and Holt v. State, 39 Tex.Crim. 282, 45 S.W. 1016 (1898), applying, without discussion, the same rule to a non-party witness in a criminal action. 
The United States Supreme Court, in Slochower v. Board of Higher Education of New York City, ${ }^{26}$ has given some indication that an adverse inference should not be drawn in a non-criminal proceeding from a valid exercise of the privilege. That case held that the summary dismissal of a publicly employed college professor, pursuant to a provision of the-New York City Charter, for exercising his privilege against self-incrimination violated the due process clause of the Fourteenth Amendment. ${ }^{27}$ The professor, while testifying before a United States Senate sub-committee investigating subversive influences in American education, had denied existing membership in the Communist Party but had refused on grounds of self-incrimination to answer questions concerning his membership in that party some twelve years previously. The Court justified its decision in part on the ground that no inference of prior wrongdoing could be drawn from the assertion of the privilege, rejecting the contention that the exercise of the privilege gave rise to an inference either that the witness's answer would have tended to prove him guilty of a crime or that he had falsely invoked the privilege and was therefore guilty of perjury. ${ }^{28}$

The opinion, however, does not fully explain why no adverse inference should arise in a non-criminal proceeding from a prior assertion of the privilege. If it is true that a witness may invoke the privilege only to shield himself from revealing incriminating facts, then it would appear that his assertion of the privilege amounts to a declaration that such facts do exist; and if such facts do not exist, then he has no right to invoke the privilege and may be guilty of perjury for doing so.

In order to resolve this issue, a determination must be made as to whether it is primarily the subject matter of the question or the nature of the answer which would be given that justifies the assertion of the privilege. If a witness may refuse to answer a question only when his actual answer, if given, would tend to incriminate him, an adverse inference can logically be drawn from his assertion of the privilege, but if a witness may refuse to answer a question whenever one of the reasonably possible answers would be incriminating, even though his actual answer would be completely non-incriminating, logic does not support such an inference. ${ }^{29}$

${ }^{28} 350$ U.S. 551 (1956), modified 351 U.S. 944 (1956).

${ }^{27}$ The pertinent section of the Charter provides that whenever a city employee utilizes the privilege against self-incrimination to avoid answering questions as to his "official conduct" his employment shall terminate. Ibid., at 552. According to the Supreme Court, this section, as interpreted and applied by the state courts, "operates to discharge every city employee who invokes the Fifth Amendment" and means that "the assertion of the privilege against self-incrimination is equivalent to a resignation." "Ibid., at 558, 554. Since a state court's interpretation of the meaning of a state statute is conclusive, the Supreme Court accepted the finding that the appellant Slochower's assertion of the privilege fell within the scope of the section. Ibid., at 554.

${ }^{28}$ Ibid., at 557 .

2 All of the commentators who contend that an adverse inference must logically be drawn from the exercise of the privilege (note 15 supra) assert or assume that the privilege may be 
The answer to an incriminating question would, if given, ordinarily fall into one or more of the following categories:

(1) An outright admission of guilt.

(2) An admission of acts constituting one or more but not all of the elements of a criminal offense. 30

(3) An admission of facts or circumstances tending to connect the witness with the commission of a crime. ${ }^{31}$

(4) An admission of facts supplying links in a chain of evidence or clues which could lead to discovery of evidence tending to connect the witness with the commission of a crime. ${ }^{32}$

(5) An answer, non-incriminatory in itself, which, if given in response to one of a series of related questions, will result in the "pinpointing" of an incriminating fact when the witness asserts his privilege. ${ }^{33}$

(6) A completely non-incriminating answer.

An answer falling into any category other than (1) could be made by a person innocent of any crime, but an answer falling into any of categories (1) through (5) is an incriminating answer because it either admits the commission of a crime or some of the elements of a crime by the witness, supplies facts tending to connect the witness with the commission of a crime, or leads to further questions or investigation which will supply such facts. ${ }^{34}$ It is clear that the self-incrimination privilege may be asserted if the answer of the witness would fall into any of categories (1) through (5), ${ }^{35}$ but may the privilege also be asserted if his answer would fall into category (6)? Thus, if a witness is asked whether he recently robbed the First National Bank may he validly assert the privilege even though his answer would be "no"?

In 1807, John Marshall, in the case of United States v. Aaron Burr, ${ }^{36}$ de-

validly exercised by a witness other than a defendant in a criminal case only when the actual answer if given would tend to incriminate. Consult 8 Wigmore, Evidence 403, 410 (3d ed., 1940 ), and other articles cited at note 15 supra.

${ }^{30}$ Consult 8 Wigmore, Evidence 354 (3d ed., 1940).

${ }^{31}$ See cases and authorities cited at note 6 supra.

${ }^{32}$ See Hoffman v. United States, 341 U.S. 479 (1951) ; Blau v. United States, 340 U.S. 159 (1950); Maffie v. United States, 209 F.2d 225 (C.A. 1st, 1954); United States v. Coffey, 198 F.2d 438 (C.A. 3d, 1952) ; United States v. Greenberg, 187 F.2d 35 (C.A. 3d, 1951); Ex parte Irvine, 74 Fed. 954 (C.C. S.D. Ohio, 1896); Falknor, Self-Crimination-Links in the Chain, 5 Vand. L. Rev. 479 (1952).

${ }^{33}$ For example, if the witness is asked: "Were you a member of the Communist Party one day ago, one week ago, one month ago, one year ago," assertion of the privilege after one or more negative answers will "pinpoint" the incriminating information. Consult Noonan, op. cit. supra note 15, at 328-31; Griswold, op. cit. supra note 6, at 17-18.

35 Consult Noonan, op. cit. supra note 15.

${ }^{35}$ Consult authorities cited notes 30-34 supra.

${ }^{30} 25$ Fed. Cas. 38 (C.C. Va., 1807). Marshall ruled that Willie, Burr's secretary, could properly assert the privilege against self-incrimination when he was asked while testifying before a grand jury, whether he understood an allegedly treasonous letter copied by him for Burr in cipher. 
clared that a witness could justifiably assert the privilege against self-incrimination only if his actual answer would in fact tend to incriminate him. According to Marshall an assertion of the privilege is valid only if the court first decides that the answer to the question may tend to incriminate the witness and the witness then declares under oath that the answer, if given, would tend to incriminate him..$^{37}$

Marshall's first requirement, that upon claim of the privilege the court must decide whether the answer may tend to incriminate the witness has been universally followed. ${ }^{38}$ The second requirement, that the witness must declare under oath that it would tend to incriminate him, has not received the same widespread acceptance. 39

Some cases, expressly or by implication, have accepted the requirement that to justify assertion of the privilege the actual answer must be one which if given would tend to incriminate. ${ }^{40}$ Thus, in Mason v. United States ${ }^{41}$ a witness was asked whether a game of cards had been played either at a table where he had been sitting or at an adjoining table. In holding his refusal to answer the question was not justified because the danger of incrimination was too fanciful or remote, the Supreme Court, citing United States v. Burr and the English case of Regina $v$. Boyes, ${ }^{42}$ stated that in order to justify assertion of the privilege a witness must have "reasonable cause to apprehend danger to himself from a direct answer to any question propounded."43 If the witness must reasonably apprehend danger to himself from the answer he would give,

${ }^{37}$ Ibid., at 40.

${ }^{23}$ Authorities cited notes $40,41,43,46,48,49,51,53,54,55$ infra.

${ }^{\infty}$ Authorities cited notes $46,48,49,51,53,54,55$ infra.

${ }^{10}$ Cases cited at notes 41 and 43 infra, and see United States v. Weisman, 111 F.2d 260 (C.A. 2d, 1940); Commonwealth v. Joyce, 326 Mass. 751, 97 N.E.2d 192 (1951); In re Berman, 105 Cal.App. 37, 287 Pac. 125 (1930); Wilson v. Ohio Farmers Insurance Co., 164 Ind. 462,73 N.E. 892 (1905) ; People ex rel. Taylor v. Forbes, 143 N.X. 219, 38 N.E. 303 (1894).

${ }^{41} 244$ U.S. 362 (1917).

21 Best \& S. 311, 121 Eng. Rep. 730 (1861).

${ }^{13}$ Mason v. United States, 244 U.S. 362, 367 (1917). In Sovereign Camp Woodmen of the World v. Bailey, 163 S.W. 683, 685 (Tex. Civ. App., 1914), the Texas appellate court, in ruling on the validity of the assertion of the privilege by certain witnesses, stated: "They should be compelled to swear unequivocally that their testimony would incriminate them, and then the court should be satisfied that there is reasonable ground to apprehend danger to the witnesses from their being compelled to answer."

In State v. Thaden, 43 Minn. 253, 255-56, 45 N.W. 447, 448 (1890), the Minnesota Supreme Court stated: "[W]hen such reasonable apprehension of danger appears, then inasmuch as the witness alone knows the nature of the answer he would give, he alone must decide whether it would criminate him. This, we think, is substantially what Chief Justice Marshall meant by his statement of the rule in the Burr trial."

In United States v. Raley, 96 F.Supp. 495, 496 (D. D.C., 1951), a United States District Court stated: "The privilege may only be asserted when there is reasonable apprehension on the part of the witness that his answers would furnish some evidence upon which he could be convicted of a criminal offense...." 
then that answer must necessarily be an incriminating one, for otherwise it would not reasonably place him in any danger of criminal prosecution. ${ }^{44}$

Other cases have departed in varying degrees from Marshall's second requirement. Many decisions, including recent ones of the Supreme Court, state that a witness may validly assert the privilege against self-incrimination if his answer to a question "could" or "might" or "may" tend to incriminate him. ${ }^{45}$ For example, in Quinn v. United States ${ }^{46}$ the Supreme Court, in upholding the refusal of a witness before a congressional investigating committee to tell whether he had ever been a Communist, stated: "Clearly an answer to the question might have tended to incriminate him. As a consequence, petitioner was entitled to claim the privilege." no mention of any requirement that the actual answer must be one which, if given, would in fact be incriminating; therefore, at least by implication, they tend to reject or abandon Marshall's second requirement. ${ }^{48}$

\footnotetext{
"Leading cases dealing with the problem of waiver of the privilege indicate that a witness who answers an incriminating question waives the right to assert the privilege as to further questions on the same subject only when his answer is incriminating. See cases cited at note 7 supra. These cases may also be interpreted as implying that the privilege can properly be invoked in response to a question only if the answer would in fact be incriminating. Consult Noonan, op. cit. supra note 15, at 323-28. This interpretation, however, is not logically compelling, because: First, the considerations involved in determining when a constitutional right is waived are different from the considerations involved in determining when that constitutional right may be exercised. Since the doctrine of waiver is a limitation upon the constitutional privilege against self-incrimination, the application of the doctrine may be restricted to incriminating answers while the right itself may still be asserted whenever the question concerns matter of an incriminating nature regardless of what the answer would be. Second, a non-incriminatory answer constitutes a waiver of the privilege only as to the question answered and not as to further incriminating questions, because there is no indication that the witness intends by such an answer to waive the privilege as to further questions. An incriminating answer, on the other hand, may more logically be held to indicate an intention by the witness to waive the privilege as to further questions concerning the same subject because the incriminating fact is revealed by that answer. See cases cited at note 7 supra, and consult Some Aspects of Waiver of the Privilege against Self-Incriminating, 18 Brooklyn L. Rev. 287 (1952). It has been urged that any waiver resulting from an answer to an incriminating question should be confined to the question answered, regardless of whether the answer is or is not incriminating, in the absence of clear evidence that the witness intended by his answer to waive the privilege as to further incriminating questions. Rogers v. United States, 340 U. S. 367, 375 et seq. (1951) (dissent).

Since the privilege permits a defendant in a criminal case to refrain from testifying, if he elects to take the stand in his own defense, he thereby waives the privilege as to all pertinent questions. 8 Wigmore, Evidence 440 et seq. (3d ed., 1940).
}

${ }^{\star}$ See cases cited at notes $46,48,51,53,57$ infra.

349 U.S. 155 (1955).

${ }^{47}$ Thid., at 162.

4s In Counselman v. Hitchcock, 142 U.S. 547, 562 (1902), the Supreme Court stated: "The object [of the constitutional provision] was to insure that a person should not be compelled, when acting as a witness in any investigation, to give testimony which might tend to show that he himself had committed a crime." (Italics added.)

In Ex parte Irvine, 74 Fed. 954, 960 (C.C. S.D. Ohio, 1896), Taft, J., stated: "The true rule is that it is for the judge before whom the question arises to decide whether an answer to the question put may reasonably have a tendency to criminate the witness, or to furnish 
Some cases, on the basis of the language used or the factual situations involved, appear to establish tests for asserting the privilege which are inconsistent with Marshall's second requirement. Thus in Arndstein v. McCarthy $y^{49}$ the Supreme Court, upon upholding the right of a bankrupt to assert the privilege, said:

It is impossible to say from mere consideration of the questions propounded, in the light of the circumstances disclosed, that they could have been answered with entire impunity. ${ }^{50}$ [Italics added.]

And in Hoffman v. United States ${ }^{51}$ the Supreme Court, in considering the right of a witness to refuse to answer a question which appeared on its face to be innocuous, stated:

To sustain the privilege, it need only be evident from the implications of the question, in the setting in which it is asked, that a responsive answer to the question or an explanation of why it cannot be answered might be dangerous because injurious disclosure could result. ... The court should have considered ... that truthful answers by petitioner to these questions might have disclosed that he was engaged in such proscribed activity.... In this setting it was not "perfectly clear, from a careful consideration of all of the circumstances in the case, that the witness is mistaken, and that the answer[s] cannot possibly have such tendency" to incriminate. ${ }^{52}$ [Italics added.]

In these cases the emphasis is on the subject matter of the question, and a witness is permitted to refuse to answer a question which under the circumstances might require an incriminating answer regardless of what the actual answer in fact would be. ${ }^{53}$ There are a number of decisions adhering to the Hoffman rule. ${ }^{54}$

proof of a link in the chain of evidence necessary to convict him of a crime. . . It must appear to the court, from the character of the question, and the other facts adduced in the case, that there is some tangible and substantial probability that the answer of the witness may help to convict him of a crime." (Italics added.)

${ }^{49} 254$ U.S. 71 (1920).

co Ibid., at 72 .

${ }^{51} 341$ U.S. 479 (1951).

62 Ibid., at 486-88.

${ }^{*}$ In Burdick v. United States, 236 U.S. 79 (1915), a city editor, called before a grand jury, refused, on grounds of self-incrimination, to state where he acquired the information contained in certain articles on fraud which appeared in his newspaper. He declined a presidential pardion as to all crimes of which he might have been guilty, tendered him by the government, and continued to assert his privilege not to testify. The Supreme Court held that Burdick could refuse to accept the pardon and could properly refuse to answer questions which might be incriminating for any personal reasons he might have. Contrary to the factual situation in most cases, it appears in this case that the witness's answer if given might well have been non-incriminating, his real motive in refusing to answer being simply to protect his sources of information. Therefore, the court's holding that under such circumstances he could properly assert his privilege against self-incrimination is at variance with the requirement that the potential answer must in fact be incriminating.

Et Emspak v. United States, 349 U.S. 190, 198 (1955) (quoting with approval the rule from the Hoffman case). In United States v. Greenberg, 187 F.2d 35, 39 (C.A. 3d, 1951), 
Further, no sanction now remains in the federal courts for the enforcement of Marshall's second requirement, because under the present rule a witness need not assert under oath that his answer would be incriminating but may claim the privilege by objection or motion. ${ }^{55}$ Thus, there can be no perjury penalty for a false assertion of the privilege, even though in an appropriate case independent evidence could well become available at a later time to show that the witness's answer, if given, would have been non-incriminating.

Although many of the foregoing cases demonstrate a tacit departure from Marshall's second requirement, there is no case which has unequivocally rejected that requirement; nor has any case isolated the issue and carefully considered it from the standpoint of social policy. An examination of the policies underlying the constitutional provisions would therefore be appropriate to determine which rule more effectively gives expression to the purposes of the privilege.

Since the privilege against self-incrimination has been most frequently asserted by persons who appear to have been involved in criminal activity, it is commonly thought that the primary purpose of the privilege is to protect persons suspected of crime from being forced to give evidence which would help to convict them of the commission of crime-in other words, that the

the court stated that in order to claim the privilege the witness was required "to satisfy the court that there was a reasonable possibility of the existence of facts in his situation and under the circumstances of his case which might convict him of a federal crime if a fact which might be disclosed by a direct answer to the controverted question were added to them." (Italics added.) In United States v. Coffey, 198 F.2d 438 (C.A. 3d, 1952), the court of appeals, interpreting Hoffman v. United States and Greenberg v. United States, held that a witness can properly refuse to answer on grounds of self-incrimination a question innocuous on its face if he can show the court how the prosecutor building on a harmless answer might conceivably, step by step, link the witness with commission of a crime, and that this suggested course is not incredible under the facts of the case. This test emphasizes the intent of the questioner rather than the content of the potential answer. The opinion requires the witness to show that the answer to the seemingly innocuous question might reasonably be used to elicit further incriminating evidence, but it does not require him to assert that the answer would in fact be so used, nor does it intimate that if the prosecutor could not actually link the witness through his answer to the commission of any crime the assertion of the privilege would be improper. See cases collected in Falknor, op. cit. supra note 32, at 485; Recent Extensions of the Witness' Privilege against Self-Incrimination, $53 \mathrm{Col}$. L. Rev. 275 (1953).

${ }^{\star}$ Quinn v. United States, 349 U.S. 155, 162-63, 165-68 (1955) ; Emspak v. United States, 349 U.S. 190, 194 (1955); Noto v. United States, 76 S.Ct. 255, 257 (1955) ; Boyd v. United States, 116 U.S. 616 (1886) ; Porter v. Heend, 6 F.R.D. 588 (N.D. III., 1947) ; Bowles v. Trowbridge, 60 F.Supp. 48 (N.D. Cal., 1945); 8 Wigmore, Evidence 390 (3d ed., 1940). See Orloff v. Willoughby, 345 U.S. 83, 91 (1953) ; Levin v. Gillespie, 121 F.Supp. 726 (N.D. Cal., 1954).

Some state courts adhere to Marshall's requirement that the claim of privilege must be made by answer under oath. Mumford v. Croft, 93 A.2d 506 (Del., 1952); 8 Wigmore, Evidence 388, 396 (3d ed., 1940). 
function of the privilege, based upon some vague principle of sportsmanship or fair play, is simply to give assistance to suspected criminals in resisting prosecution. ${ }^{56}$ The inclusion in federal and state constitutions of such a serious limitation upon the power of the government to apprehend and punish criminals, however, arises from more basic social considerations than the desire to give criminals a sporting chance.

One of the most important functions of the privilege is to protect all persons, whether suspected of crime or not, from abuse by the government of its powers of investigation, arrest, trial and punishment. ${ }^{57}$ It was not solicitude for persons accused of crime but the desire to maintain the proper balance between government and the persons governed that gave rise to the adoption of these constitutional provisions. Without the restrictions imposed by the privilege, and in the absence of statutory limitations, any number of persons could be rounded up by the police, brought before a magistrate, grand jury or even a legislative committee investigating crime, placed under oath and cross-examined to determine whether they had committed any crimes. Without the protection of the privilege a person, simply upon accusation of crime, could be forced to submit to an inquisition, under oath, concerning his actions. A refusal to answer could be construed as an admission of guilt and might also subject him to punishment for contempt. Such procedures would convert our traditional methods of criminal prosecution into an "inquisitorial" system under which the police and prosecuting authorities would have far greater power over the actions of private citizens than has heretofore been accorded them. ${ }^{58}$

This view of the function of the privilege is confirmed by the history of its

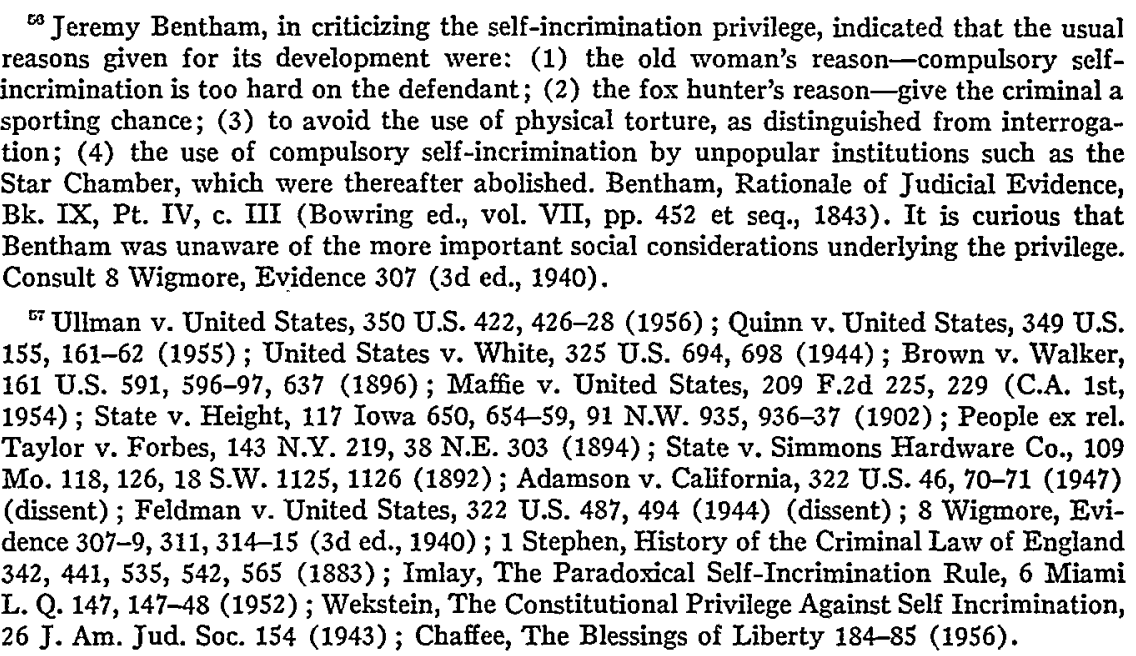

${ }^{5}$ See cases and authorities cited note 57 supra. 
development. Enactment of the American constitutional provisions reflected the English and colonial struggle against compulsory examination under oath in penal matters. That struggle was primarily concerned not so much with shielding witnesses from incriminating disclosures as with limiting the inquisitorial power of government officals. ${ }^{59}$

In England the privilege developed as a curb upon the power of the ecclesiastical and prerogative courts to force persons to appear and answer under oath questions concerning their beliefs and political activities. ${ }^{60}$ In America

${ }^{50}$ Consult Chaffee, op. cit. supra note 57, at 189-209. The drafters of the American constitutional provisions may also have been influenced by contemporary French and Italian writers who likewise emphasized the importance of limiting the inquisitorial power of the state. Consult 8 Wigmore, Evidence 302, n. 113 (3d ed., 1940) ; Franklin, Encyclopédiste Origin and Meaning of the Fifth Amendment, 15 Lawyers Guild Rev. 41 (1955); Ullman v. United States, 350 U.S. 422, 450-55 (1956) (dissent).

${ }^{\infty}$ At an early point in British history the ecclesiastical courts, in order to nullify the defense of compurgation, whereby the defendant could exonerate himself by having "oath helpers" swear that he was innocent (8 Wigmore, Evidence 279-81 [3d ed., 1940]), developed the requirement that an accused himself must answer questions under oath concerning his guilt. Ibid., at 280-81. Initially, an accused could not be called upon to answer in such manner unless there was some prior accusation against him. Ibid., at 284-86. However, in the pursuit of heretics this procedure was rapidly abused, and under Elizabeth the prerogative court of the Star Chamber and the ecclesiastical court of the High Commission exercised broad power to administer the oath $e x$ officio and question suspects without any prior accusation having been made against them. Ibid. Chaffee, op. cit. supra note 57, at 189-209.

There was much popular agitation, particularly among the Puritans and Separatists, against the power of these courts to force persons to appear and answer under oath questions concerning their beliefs and activities. Pittman, The Colonial and Constitutional History of the Privilege against Self Incrimination in America, 21 Va. L. Rev. 763, 770 (1935); 8 Wigmore, Evidence 286-87 (3d ed., 1940) ; UlIman v. United States, 350 U.S. 422, 446-55 (1956) (dissent) ; Maguire, "Attack of the Common Lawyers on the Oath ex officio as Administered in the Ecclesiastical Courts in England," Essays in History and Political Theory, c. VII (1936). In about 1616 Coke ruled that the High Commission could not administer the oath ex officio in penal matters and was confined to its traditional ecclesiastical jurisdiction over testamentary and matrimonial matters. 8 Wigmore, Evidence 288-89 (3d ed., 1940). At an earlier time Coke had obtained a writ of prohibition against the jurisdiction of the ecclesiastical courts by arguing the maxim "nemo tenetur prodere se ipsum" (no one should be required to accuse himself). Griswold, The Fifth Amendment Today 2 (1955). In 1637 John Lilburn refused before the court of the Star Chamber to answer questions concerning matters as to which there had been no accusation against him. He was punished by the court, but Parliament declared the action illegal and ordered monetary compensation for the punishment he had suffered. 8 Wigmore, Evidence 291 (3d ed., 1940); Trial of John Lilburn, 3 How. St. Tr. 1315 (1637). Consult also Trial of James Udall, 1 How. St. Tr. 1271 (1590); Chaffee, op. cit. supra note 57, at 193-97.

Shortly thereafter, in 1641, the Long Parliament, as part of its struggle with Charles I, abolished the courts of the Star Chamber and the High Commission, forever denying to any ecclesiastical court the power to administer an ex officio oath in penal matters. 16 Car. I, cc. 10, 11 (1641) ; Pittman, op. cit. supra, at 772; 8 Wigmore, Evidence 292 (3d ed., 1940). During the Rebellion demands were made by Cromwell's Army and by the Levellers for legislation establishing that no person could be forced to answer under oath questions against himself in any criminal case. Pittman, op. cit. supra, at 772-73; 3 Haller, Tracts on Liberty in the Puritan Revolution 403 (1934).

Meanwhile, in the common-law courts up until Lilburn's trial an accused apparently could be examined under oath in a preliminary examination and forced to answer questions 
the colonists objected to inquisitorial methods used by royal governors and their councils, acting as prerogative courts, and adopted provisions against compulsory self-incrimination to avoid enforced questioning at the will of the executive. ${ }^{61}$ The colonists also adopted such provisions to prevent extraction of confessions by physical torture. ${ }^{62}$ This motive, too, reflects a concern, not with the incriminatory nature of the answer extracted, but with inquisitorial procedure. Torture is no less objectionable if the victim refuses to give an incriminating answer.

The American system of criminal justice is designed to apprehend and punish most offenders and at the same time to protect innocent persons against the invasion of personal liberties which could result from unrestricted government action to ferret out criminals. This policy of limiting the power which the police may exercise over private citizens when investigating and apprehending criminals is manifested not only in the self-incrimination clause of the Fifth Amendment, but also in the illegal search and seizure provision of the Fourth Amendment and in due process clauses of the Fifth and Fourteenth Amendments. Thus, the Supreme Court has held that the enforced production in court of incriminating private papers violates both the self-incrimination and search and seizure provisions, ${ }^{63}$ and that the introduction in court of an involuntary confession violates both the self-incrimination

concerning his offense. 8 Wigmore, Evidence 293-97 (3d ed., 1940). At the actual trial, however, he was not placed under oath and, although he could be examined at length concerning his offense, he could not be compelled to answer. Ibid. Although Lilburn had asserted only that he could not be forced to answer questions concerning offenses of which he did not stand accused, from his trial evolved the principle that no person need answer questions of an incriminating nature. Ibid., at 298-99. In 1649 Lilburn again on trial, this time in a common law court for treason, successfully refused to answer any questions concerning his guilt saying: "Thou . . s sayest it they are by books. But prove it." Ibid. 4 How. St. Tr. 1269, 1292,1342 (1649).

By 1700 it was settled in England that no person could be required to answer before any court questions under oath in penal matters regardless of prior accusation. 8 Wigmore, Evidence 292-93, 298-300 (3d ed., 1940) ; Griswold, op. cit. supra, at 3-4.

${ }^{61}$ Pittman, op. cit. supra note 60, at 775, 783-87; Chaffee, op. cit. supra note 57, at 189-92, 206-9; Griswold, op. cit. supra note 60, at 4; Ullman v. United States, 350 U.S. 422, 447-50 (1956) (dissent). In Massachusetts Colony no inquisitorial oath could be administered at all (Pittman, op. cit. supra note 60, at 778-79), and in Virginia no person could be compelled "to swear against himself" in any matter in which he was liable to corporal punishment. Ibid., at 781; Va. Stat. (Hening, 1792) vol. II, 422.

${ }^{\text {e2 }}$ Pittman, op. cit. supra note 60 , at 783 ; Morgan, The Privilege against Self-Incrimination, 34 Minn. L. Rev. 1, 22 (1949) ; Ullman v. United States, 350 U.S. 422, 447-48 (1956) (dissent) ; Chaffee, op. cit. supra note 57 , at 188-89.

Boyd v. United States, 116 U.S. 616 (1886). See State v. Height, 117 Iowa 650, 661-65, 91 N.W. 935, 938-40 (1902); Corwin, The Supreme Court's Construction of the Self-Incrimination Clause, 29 Mich. L. Rev. 1, 14-15 (1930). Although enforcement of the illegal search and seizure clause often has the effect of protecting criminals from apprehension, it is intended as a restriction on the broad power of the police to encroach upon the persons and property of private citizens, and the search and seizure and self-incrimination provisions in effect reflect the same basic principle. 
and due process provisions. ${ }^{64}$ Admittedly, under this system some criminals will go free, but the founders of our government considered this a necessary price to pay in order to provide a safeguard against excessive power in the hands of law enforcement officials. ${ }^{65}$

As a second important function, the self-incrimination privilege establishes a fair procedure for criminal trials. ${ }^{66}$ The prosecution is required by the privilege to present its case first so that the accused may hear the evidence and be confronted with the witnesses against him. He may then present his defense, calling such witnesses and offering such evidence as he deems fit. Without the privilege the prosecution, in the absence of a statute to the contrary, could call the accused as the first witness and attempt to elicit from him not only incriminating admissions but also derogatory collateral information and inaccurate statements on collateral details. ${ }^{67} \mathrm{~A}$ person accused of crime may become confused and frightened under cross-examination. ${ }^{68}$ His memory may be faulty with respect to unanticipated collateral matters. He may be subject to impeachment for prior conviction of felony. Other aspects of his behavior may be unfavorable if revealed. ${ }^{69} \mathrm{He}$ is therefore accorded the right to elect

Bs Bram v. United States, 168 U.S. 532 (1897). See State v. Height, 117 Iowa 650, 91 N.W. 935 (1902); Rochin v. California, 342 U.S. 165, 174-213 (1952) (concurrences); The Privilege against Self-Incrimination: Does It Exist in the Police Station?, 5 Stanford L. Rev. 459 (1953) ; Model Code of Evidence, Rule 203. Cf., 8 Wigmore, Evidence 387 (3d ed., 1940). The proscription placed by the due process clause on the use of involuntary confessions sometimes protects criminals from conviction, but its purpose is to place a barrier between the individual citizen and the exercise of unrestrained police authority. Such confessions are excluded, not only because of their unreliability from an evidentiary standpoint, but also because it is socially desirable to discourage the use of coercive methods by the police in obtaining such confessions, even if they are true. Rochin v. California, 342 U.S. 165, 173 (1952). The due process and self-incrimination provisions in this respect reflect the same basic constitutional policy.

${ }^{\infty}$ Maffie v. United States, 209 F.2d 225, 229 (C.A. 1st, 19.54) ; United States v. White, 322 U.S. 694, 698 (1944); Bram v. United States, 168 U.S. 532 (1897); Boyd v. United States, 116 U.S. 616 (1886); State v. Simmons Hardware Co., 109 Mo. 118, 126, 18 S.W. 1125,1126 (1892).

${ }^{68}$ See State v. Edelman, 19 N.J.Super. 350, 88 A.2d 516 (1952); Matter of Peck, 167 N.Y. 391, 60 N.E. 775 (1901) ; State v. Simmons Hardware Co., 109 Mo. 118, 18 S.W. 1125 (1892) ; Imlay, op. cit. supra note 57, at 149; Wekstein, op. cit. supra note 57, at 154-56; Griswold, op. cit. supra note 60, at 9; Chaffee, op. cit. supra note 57, at 206-7.

${ }^{6}$ See Brown v. Walker, 161 U.S. 591, 596-97, 637 (1896) ; People v. Talle, 111 Cal.App. 2d 650, 245 P.2d 633 (1952); State v. Height, 117 Iowa 650, 91 N.W. 935, 937 (1902); Commonwealth v. Smith, 163 Mass. 411, 40 N.E. 189, 196-97 (1895); Noonan, op. cit. supra note 15 , at 319 .

${ }^{\text {es }}$ Brown v. Walker, 161 U.S. 591, 596-97, 637 (1896) ; Wilson v. United States, 149 U.S. 60,66 (1893) ; State v. Height, 117 Iowa 650, 657, 91 N.W. 935, 937 (1902). Consult Griswold, op. cit. supra note 60 , at 20 ; Wekstein, op. cit. supra note 57 , at 154-55; Mandatory Dismissal of Public Personnel and the Privilege against Self-Incrimination, $101 \mathrm{U}$. of Pa. L. Rev. 1190, 1200 (1953).

${ }^{\infty}$ See People v. Sorge, 301 N.Y. 198, 93 N.E.2d 637 (1950) ; State v. Palko, 121 Conn. 669, 186 Atl. 657 (1936); Noonan, op. cit. supra note 15, at 319. 
whether or not he will testify and to defer this election until after the prosecution has made out a prima facie case against him.

For the same reasons a witness may also refuse to answer questions of an incriminating nature before grand juries, legislative investigating committees, and other bodies authorized to compel testimony under oath. ${ }^{70}$ Otherwise, the prosecution by arranging to have an accused subpoenaed to appear as a witness before any such body could force him to testify prior to presentation of its case in court and thereby accomplish what it could not accomplish at the trial. ${ }^{71}$ Thus, the privilege against self-incrimination has the effect of placing on the prosecution the burden of producing evidence sufficient to prove the guilt of the accused before he is called upon to present his defense. ${ }^{72}$

The privilege against self-incrimination is also a constitutional facet of the right of privacy. ${ }^{73}$ The right of each individual to remain unmolested in the absence of independent evidence connecting him with the commission of a crime is but an aspect of the limitation which the privilege places upon the

${ }^{70}$ Quinn v. United States, 349 U.S. 155, 161-62 (1955) ; Blau v. United States, 340 U.S. 159 (1950); Counselman v. Hitchcock, 142 U.S. 547 (1892); Boyd v. United States, 116 U.S. 616 (1886); McCarthy v. Arndstein, 262 U.S. 355 (1923) ; State v. Height, 117 Iowa 650, 656, 91 N.W. 935, 937 (1902).

${ }^{71}$ Consult Griswold, op. cit. supra note 60 , at 22,55 . It has been suggested that the privilege should be narrowly construed to apply only to defendants on trial in criminal cases. Consult April, A Re-appraisal of the Immunity from Self-Incrimination, 39 Minn. L. Rev. 75 (1954). The privilege, however, would have little vitality if it were to protect a defendant from being compelled to give evidence against himself in a criminal trial but not from being compelled in another proceeding to give evidence which could then be used against him in a criminal trial. Consult Griswold, op. cit. supra note 60 , at 54-55. The use of the phrase "in any criminal case" in the Fifth Amendment was intended not to confine the application of the privilege to defendants in criminal cases but to negative any implication that the privilege protected a party in a civil case from being compelled to be a witness against himself as to non-criminal matters revealing civil liability. Consult Col. L. Rev., op. cit. supra note 18.

${ }^{72}$ See cases and authorities cited at note 66 supra. The self-incrimination privilege is closely related to other constitutional guarantees of a fair trial. Due process of law requires that the prosecution sustain the burden of proving the defendant guilty of a crime. Tot $v$. United States, 319 U.S. 463, 473 (1943) ; McFarland v. American Sugar Refining Co., 241 U.S. 49 (1916) ; Bailey v. Alabama, 219 U.S. 219, 239 (1911) ; People v. Terra, 303 N.Y. 332, 102 N.E.2d 576 (1951) ; State v. Grimmett, 33 Idaho 203, 103 Pac. 380 (1920). Due process, as well as the self-incrimination privilege, would probably also prevent the prosecution from calling the defendant as a witness. See Bram v. United States, 168 U.S. 532 (1897). The first sentence of the Fifth Amendment requires an indictment by a grand jury before trial for a serious crime, and the Sixth Amendment requires that the accused be informed of the nature and cause of the accusation and be confronted with the witnesses against him. Consult Chaffee, op. cit. supra note 57 , at 206-7.

${ }^{73}$ Boyd v. United States, 116 U.S. 616 (1886) ; Bednarik v. Bednarik, 18 N.J. Misc. 633, 16 A.2d 80 (1940). See Rochin v. California, 342 U.S. 165, 172, 211-13 (1952); State v. Height, 117 Iowa 650, 657-59, 91 N.W. 935, 937 (1902) ; Corwin, op. cit. supra note 63, at 15 ; Blood Grouping Tests and the Constitutional Immunities against Self-Incrimination and Personal Privacy, 1 Bill of Rights Rev. 226 (1941); 8 Wigmore, Evidence 314 (3d ed., 1940). 
powers of the police. The privilege reflects the further principle, however, that a person's own knowledge of whether or not he has any connection with a criminal act is private to him and should not be subject to compulsory disclosure. ${ }^{74}$ The dignity of the individual is thereby protected from the degradation of enforced response to questions concerning possible wrongdoing. ${ }^{75}$

Lastly, the privilege has the effect of encouraging persons having information pertinent to a trial or inquiry to come forward freely with their testimony. If such witnesses could be forced to answer all material questions concerning possible criminal conduct on their part, many would be reluctant to testify and more readily would conceal the evidence they possessed. The privilege relieves them from the fear of being cross-examined on such possibly incriminating matters. ${ }^{76}$

Marshall's second requirement does not effectively implement these policies. Thus, the privilege would have little effect in limiting the power of law enforcement officials if it could be asserted only when the answer of the witness, if given, would in fact tend to incriminate him. Under that interpretation, and in the absence of a statute, such officials would still be free to arrest any person and to have him interrogated under oath before a grand jury, legislative committee or committing magistrate about possibly incriminating matters. Since he could properly withhold only those answers which would in fact be incriminating, each refusal to answer would itself acknowledge the existence of incriminating facts. While this might be an effective way to detect criminals, it is the sort of procedure which the privilege is designed to prevent. If, on the other hand, the privilege may be invoked as to any question which might reasonably give rise to an incriminating answer, regardless of whether the answer would in fact be incriminating, assertion of the privilege at the outset would forestall such interrogation.

Further, if the privilege were available only when the actual answer, if given, would in fact tend to incriminate, the prosecution could evade its

${ }^{74}$ See Sinclair v. United States, 279 U.S. 263 (1929).

${ }^{75}$ See Griswold, op. cit. supra note 60, at 7-8; Ullman v. United States, 350 U.S. 422, 445-46, 449 (1956) (dissent) ; State v. Height, 117 Iowa 650, 657-58, 91 N.W. 935, 937 (1902).

The privilege, however, has been held not to apply to questions calling for answers which might subject the witness to infamy or disgrace so long as a criminal act is not involved, and a witness can be questioned concerning even criminal acts if a statute makes him immune from conviction. Ullman v. United States, supra, at 422 ; Burdick v. United States, 236 U.S. 79, 94 (1915); Brown v. Walker, 161 U.S. 591 (1896). It would seem, however, that fuller constitutional protection of the right of privacy would extend the privilege to such questions as well. Ullman v. United States, supra, at 440-55 (dissent); Brown v. Walker, supra, at 631 (dissent) ; United States v. James, 60 Fed. 257, 264 (N.D. Ill., 1894). 187.

${ }^{\circ}$ Consult 8 Wigmore, Evidence 307 (3d ed., 1940) ; Wekstein, op. cit. supra note 57, at 
burden of proving the guilt of the accused before he presents his defense by calling him as a witness at the outset of the trial and compelling him to reply whenever his answer would not be incriminating. He could thus be forced to answer questions on collateral matters which might be derogatory or concerning which he might thereafter be impeached, and his assertion of the privilege at any point during the interrogation would, in practical effect, constitute an admission in open court that his answer would in fact be incriminating. ${ }^{77}$ The right of a defendant in a criminal case to refuse to testify as a witness is a logical corollary of the privilege only if the privilege can be asserted as to questions concerning matter of an incriminating nature regardless of what the answers would be, because while any question material to the case is of an incriminating nature when put to the accused, ${ }^{78}$ his answer to any such question may well be non-incriminating.

An interpretation permitting the assertion of the privilege only when the answer would in fact be incriminating likewise does not protect the privacy of an individual's own knowledge concerning his connection with a criminal act. That interpretation permits interrogation of a witness concerning any activity relating to the commission of crime, and his assertion of the privilege becomes a forced revelation that facts tending to incriminate him do exist. If, however, the witness may assert the privilege whenever the question concerns matter of an incriminating nature, regardless of what the answer would be, he can avoid revealing the existence of incriminating facts and thereby preserve his right of privacy.

Finally, if persons possessing information pertinent to a trial or inquiry are to be encouraged to come forward freely with their testimony, they should be permitted to assert the privilege whenever the question relates to an incriminating matter. If they can assert the privilege only when the answer, if given, would in fact incriminate them, then they must submit to interrogation concerning possible criminal activity on their part, when material to the proceedings, and they cannot assert the privilege without in effect admitting that facts tending to incriminate them do exist.

Thus, it appears that the purpose of the privilege is to prevent interrogation of any witness concerning matters which reasonably might incriminate him. The privilege places a limitation on the questioner; it restrains him from asking questions designed to elicit information of an incriminating nature by permitting the witness to refuse to answer such questions. In order to enforce the policies of the privilege, a witness must be free to invoke it whenever the question is improper, regardless of what his actual answer would be.

\footnotetext{
${ }^{77}$ Consult 8 Wigmore, Evidence 392-93 (3d ed., 1940); Philadelphia v. Cline, $158 \mathrm{~Pa}$. Super. 179, 44 A.2d 610 (1945),

${ }^{78}$ See Johnson v. United States, 318 U.S. 189, 195 (1943) ; 8 Wigmore, Evidence 356, 392, 440-41 (3d ed., 1940).
} 
Since Marshall's second requirement appears to be inconsistent with the social policies implicit in the self-incrimination privilege, that requirement should be abandoned. In its place the following rules are suggested as a basis for determining when the privilege may be validly asserted:

(1) Whenever a question shows on its face that it is designed to find out whether or not a witness has committed an illegal act or has engaged in activities which might reasonably constitute evidence of, or furnish clues as to the commission of, such an act, he may invoke the privilege, even though his answer would not incriminate him. ${ }^{79}$

(2) If a question does not show on its face that it is designed to find out whether or not the witness has committed an illegal act or engaged in related activities, he may invoke the privilege, even though his answer would not incriminate him, provided he can show to the satisfaction of the court that the question is in fact designed to elicit such information. In making this showing he may refer to extrinsic matters which bear upon the purpose for which the question is asked, such as statements and actions of law enforcement officers, statements of other witnesses, articles in the public press, his own reputation and the reputation of persons referred to in the question. ${ }^{80}$

(3) If a question is innocent on its face and is not designed to elicit incriminating information, the witness may invoke the privilege provided he can show that one of the possible answers, which is not too remote or fanciful, would be incriminating. In making this showing he may refer to extrinsic matters such as his own reputation and the reputations of persons referred to in the question. 81

If a witness may thus assert the privilege against self-incrimination even though his answer, if given, would not in fact be incriminating, it is clear that logic does not compel an inference from the assertion of the privilege that facts tending to incriminate the witness do exist. The argument that no person would actually assert the privilege unless his answer would in fact tend to incriminate him $^{82}$ is not persuasive, because there are a variety of psychologically compelling motives for asserting the privilege other than fear of

${ }^{70}$ See Quinn v. United States, 349 U.S. 155, 162-63 (1955) ; Emspak v. United States, 349 U.S. 190 (1955) ; Arndstein v. McCarthy, 254 U.S. 71 (1920) ; Burdick v. United States, 236 U.S. 79 (1915) ; Counselman v. Hitchcock, 142 U.S. 547 (1892); United States v. St. Pierre, 128 F.2d 979 (C.A. 2d, 1942); Ex parte Irvine, 74 Fed. 954 (C.C. S.D. Ohio, 1896).

${ }^{80}$ See Hoffman v. United States, 341 U.S. 479 (1951) ; Maffie v. United States, 209 F.2d 225 (C.A. 1st, 1954); United States v. Coffey, 198 F.2d 438 (C.A. 3d, 1952); United States v. Greenberg, 187 F.2d 35 (C.A. 3d, 1951); Alexander v. United States, 181 F.2d 480 (C.A. 9th, 1950).

${ }^{81}$ Authorities cited note 80 supra. See, also, Mason v. United States, 244 U.S. 362 (1917); Ex parte Irvine, 74 Fed. 954 (C.C. S.D. Ohio, 1896) ; Commonwealth v. Joyce, 326 Mass. 751, 97 N.E.2d 192 (1951); Abrams v. United States, 64 F.2d 22 (C.A. 2d, 1933).

${ }^{82}$ Consult Griswold, op. cit. supra note 60 , at 57 , and articles cited note 15 supra. 
incrimination. ${ }^{83}$ Such motives are personal to the witness and do not determine his right to assert the privilege. That right exists independently of motive. $^{84}$ If the nature of the question permits the witness to invoke the privilege, he may do so on the basis of any motive, reasonable or unreasonable. ${ }^{85}$ The issue is not legal justification but psychological motivation.

Some of the motives for asserting the privilege, other than the fear of incrimination, are:

(1) The witness is not guilty of any crime but does not wish to reveal suspicious facts or circumstances which might lead to criminal prosecution against him. ${ }^{86}$

(2) The witness does not wish to reveal suspicious facts or circumstances tending to connect friends, associates, or members of his family with the commission of a crime. ${ }^{87}$

(3) The defendant in a criminal prosecution feels he would make a poor impression as a witness or wants to avoid being impeached on collateral details or being forced to reveal derogatory collateral information. 88

(4) The witness either does not know what other witnesses have said about him, or is aware that other witnesses have testified to incriminating acts on his part and he does not wish to risk a possible prosecution for perjury by truthfully denying incriminating acts. ${ }^{89}$

(5) The witness dislikes or disapproves of the questioner or the tribunal or committee before which he is appearing and exercises his privilege as a means of expressing his dislike or disapproval.90

(6) The witness believes as a matter of principle that the tribunal or committee should not inquire into associations or beliefs. ${ }^{91}$

(7) The witness does not wish to reveal non-incriminating facts of a derogatory

${ }^{53}$ Consult Mandatory Dismissal of Public Personnel and Privilege against Self Incrimination, 101 U. of Pa. L. Rev. 1190, 1199-1200 (1953) ; Byse, Teachers and the Fifth Amendment, $102 \mathrm{U}$. of Pa. L. Rev. 871, 874-81 (1954); Griswold, op. cit. supra note 60, at 10-28, $57-68$.

st Burdick v. United States, 236 U.S. 79, 94 (1915); United States v. Shaughnessy, 212 F.2d 128, 129 (C.A. 2d, 1954); United States v. St. Pierre, 128 F.2d 979, 980 (C.A. 2d, 1942); Ex parte Irvine, 74 Fed. 954, 964 (C.C. S.D. Ohio, 1896). See Steinmetz v. State Board of Education, 44 Cal.2d 816, 825, 285 P.2d 617, 622 (1955) (dissent).

${ }^{85}$ Authorities cited note 84 supra.

${ }^{80}$ Authorities cited notes 5 and 6 supra.

${ }^{87}$ United States v. Shaughnessy, 212 F.2d 128, 129 (C.A. 2d, 1954); Griswold, op. cit. supra note 60, at 16, 25-26; Byse, op. cit. supra note 83 , at 874 et seq.; Chaffee, op. cit. supra note 57 , at $213-14,226-28$.

${ }^{85}$ Authorities cited notes 68 and 69 supra.

${ }^{8}$ Consult Griswold, op. cit. supra note 60 , at 18,21 ; Byse, op. cit. supra note 83 , at 880 ; $101 \mathrm{U}$. of Pa. L. Rev., op. cit. supra note 83, at 1199-1200; Aiuppa v. United States, 201 F.2d 287, 303 (C.A. 6th, 1952).

${ }^{\infty}$ Consult Griswold, op. cit. supra note 60 , at 67 ; Byse, op. cit. supra note 83 , at 880 .

${ }^{91}$ Consult Griswold, op. cit. supra note 60 , at 58-61; Chaffee, op. cit. supra note 57 , at 207 ; Byse, op. cit. supra note 83 , at $880 ; 101 \mathrm{U}$. of Pa. L. Rev., op. cit. supra note 83, at 1199-1200. 
nature in order to protect his reputation, social position, or for other personal reasons.

(8) The witness wishes to avoid any publicity resulting from an answer to the question. ${ }^{92}$

(9) The witness wishes to protect his sources of information.93

(10) The witness fears reprisals from other persons whose connection with a crime may be revealed by his answer. ${ }^{04}$

(11) The witness believes that in order to effectuate the purposes of the constitutional provision against self-incrimination, it is the duty of every person to assert the privilege whenever an incriminating question is asked. ${ }^{95}$

It is undoubtedly true that many, perhaps most, witnesses who assert the privilege do so to avoid revealing incriminating matter, but the same adverse motive should not be attributed to everyone invoking the privilege so long as there are other motives which may apply. The decision as to whether or not a person has engaged in activities of an incriminating nature should be made on the basis of independent evidence without regard to the exercise of the privilege against self-incrimination.

\section{Discharge of Public Employees for Asserting the Privilege}

An inference of wrongdoing would provide a possible basis for the discharge of public employees who assert the self-incrimination privilege. Without that inference such discharges are valid only if supportable on other grounds.

Like any other person, a public employee may invoke the privilege when testifying before a tribunal or committee authorized to compel attendance of witnesses and to administer oaths. It is less clear that he may invoke it when required by his employer to set forth in an oath or affidavit information concerning matters of an incriminating nature. If he refuses to answer an incriminating question before a body authorized to compel testimony, he may be punished for contempt unless he asserts the privilege, but he cannot be punished for contempt if he refuses to execute an oath or affidavit relating to his employment. He is thus in a sense free to withhold the required information. He will, however, be discharged if he does. A strong element of compulsion is therefore present, since he must choose between giving the information and losing his job.

The privilege should be available whenever public authorities attempt by physical or psychological pressure to compel a person to answer questions about incriminating matters. ${ }^{96}$ It has been held applicable to involuntary

${ }^{92}$ United States v. Shaughnessy, 212 F.2d 128, 129 (C.A. 2d, 1954).

${ }^{23}$ Burdick v. United States, 236 U.S. 79 (1915).

At United States v. St. Pierre, 128 F.2d 979, 980 (C.A. 2d, 1942).

${ }^{\infty}$ Consult note 160 infra.

${ }^{\infty}$ Holt v. United States, 218 U.S. 245, 252-53 (1910) ; Bram v. United States, 168 U.S. 532 (1897); Rochin v. People, 342 U.S. 165, 211-13 (1952) (concurrence). 
confessions, ${ }^{97}$ to questions of an incriminating nature in a loyalty certificate relating to an application for an Army commission, ${ }^{98}$ and when a refusal to execute an oath or affidavit concerning incriminatory matters would otherwise result in forfeiture or punishment. ${ }^{99}$ Hence, the threat of loss of employment for refusal to execute an oath or affidavit would appear to constitute compulsion sufficient to justify assertion of the privilege. ${ }^{100}$

A requirement by a public employer that its employees set forth in an oath or affidavit information concerning matters of an incriminating nature, therefore, is subject to the right of such employees to assert the privilege in response thereto. Assertion of the privilege necessarily results in a failure to execute the required oath or affidavit, but such failure is justified by the exercise of the privilege. A discharge for failure to execute such oath or affidavit after the privilege had been asserted would thus constitute a discharge for asserting the privilege, just as holding a witness in contempt for failure to furnish the information called for by a question to which he had validly asserted the self-incrimination privilege would amount to holding him in contempt for exercising the privilege.

A public employer is not in the same position as a private employer with respect to discharge of employees. In the absence of contractual or statutory limitations a private employer may fire his employees at will. ${ }^{101} \mathrm{~A}$ public employer is subject to constitutional limitations in discharging employees. If the United States is the employer, it is limited in its actions by the federal Constitution; ${ }^{102}$ states or their subdivisions are limited by applicable provisions of both state and federal constitutions. ${ }^{103} \mathrm{~A}$ public employer thus in a sense occupies a dual capacity with regard to its employees. As an employer

$"$ Consult authorities cited note 64 supra.

${ }^{99}$ Orloff v. Willoughby, 345 U.S. 83, 91 (1953); Levin v. Gillespie, 121 F.Supp. 726 (N.D. Cal., 1954).

${ }^{90}$ Matter of Peck, 167 N.Y. 391, 394-96, 60 N.E. 775, 776 (1901) ; State ex rel. Attorney General v. Simmons Hardware Co., 109 Mo. 118, 18 S.W. 1125 (1891). See Pockman v. Leonard, 39 Cal.2d 676, 249 P.2d 267 (1952). Cf. Hickman v. London Assurance Corp., 184 Cal. 524, 195 Pac. 45 (1920).

${ }^{100}$ Deprival of livelihood has been held to be a form of punishment. United States v. Lovett, 328 U.S. 303, 336 (1946) ; Frost Trucking Co. v. R.R. Comm'n, 271 U.S. 583, 593 (1926) ; Cummings v. Missouri, 4 Wall. (U.S.) 27\%, 323 (1866); Opinion of the Justices, 332 Mass. 763, 765, 126 N.E.2d 100, 102-3 (1955).

${ }^{101}$ Odell v. Humble Oil \& Refining Co., 201 F.2d 123, 128 (C.A. 10th, 1953). See Horowitz, Legal Aspects of Political Blacklisting in the Entertainment Industry, 29 So. Calif. L. Rev. 263, at 264 et seq. (1956) ; Loyalty and Private Employment: The Right of Employers To Discharge Suspected Subversives, 62 Yale L. J. 954 (1953).

${ }^{102}$ United States v. Lovett, 328 U.S. 303 (1946). See United Public Workers v. Mitchell, 330 U.S. 75, 100 (1947); Ex parte Curtis, 106 U.S. 371 (1882).

${ }^{103}$ Slochower v. Board of Higher Education, 350 U.S. 551 (1956) ; Wieman v. Updegraff, 344 U.S. 183 (1952); Garner v. Los Angeles Board, 341 U.S. 716 (1951); State ex rel. Christian v. Barry, 123 Ohio St. 458, 175 N.E. 855 (1931). 
it may insist that they perform their duties efficiently and in consonance with the best interests of the employer; as a government it must in all its actions respect their constitutional rights.

Penalizing a person for asserting the self-incrimination privilege in effect defeats the privilege. Therefore the constitutional provision creating the privilege must protect an individual not only from punishment for refusing to answer an incriminating question but also from punishment for invoking the privilege..$^{104}$ Since deprival of livelihood is a form of punishment, ${ }^{105}$ it would seem that neither the federal government, which is limited by the Fifth Amendment, nor any state having a self-incrimination clause in its own constitution could validly discharge a public employee for exercising the privilege..$^{106}$

Nevertheless, if a public employer requires, as a condition of employment, that employees refrain from exercising the privilege, it can be argued that an employee may retain his employment only while the condition is met and that his discharge upon breach of the condition is not a "punishment" imposed by the employer but simply the enforcement of a contractual right.

A condition which requires the surrender of a constitutional right, however, may be an unconstitutional condition. It has been held in a variety of situations that a state cannot abrogate a constitutional right by making the forbearance of that right a condition of carrying on a lawful activity and that a person is not bound to relinquish the privilege of carrying on the activity upon failure to comply with such a condition. ${ }^{107}$ On the other hand, a number of cases have upheld limitations on constitutional rights imposed as a condition of carrying on a lawful activity, some using the rationale that if a state may withhold entirely the privilege of carrying on the activity, it may confer the privilege subject to any condition it wishes. ${ }^{108}$

${ }^{19}$ Orloff v. Willoughby, 345 U.S. 83, 91 (1953); Opinion of the Justices, 332 Mass. 763, 765,126 N.E.2d 100, 102-3 (1955) ; In re Holland, 377 Ill. 346, 356-57, 36 N.E.2d 543, 548 (1941).

${ }^{10}$ See cases cited at note 100 supra.

${ }^{100}$ Consult 101 U. of Pa. L. Rev., op. cit. supra note 83, at 1193-94.

${ }^{1 \pi}$ Hague v. C.I.O., 307 U.S. 496, 515 (1939) ; Frost Trucking Co. v. R.R. Comm'n, 271 U.S. 583, 593 (1926); Terral v. Burke Constr. Co., 257 U.S. 529 (1922); Western Union Telegraph Co. v. Kansas, 216 U.S. 1 (1910); Alston v. School Board of Norfolk, 112 F.2d 992, 997 (C.A. 4th, 1940) ; Danskin v. San Diego School District, 28 Cal.2d 536, 171 P.2d 885 (1946) ; State ex rel. Christian v. Barry, 123 Ohio St. 458 , 175 N.E. 855 (1931). See Opinion of the Justices, 332 Mass. 763, 765, 126 N.E.2d 100, 102-3 (1955).

Knowledge of such a condition by a public employee at the time he entered upon his employment would not bind him to it contractually if the public agency could not constitutionally impose it. Alston v. School Board of Norfolk, supra, at 997; State v. Barry, supra. See other cases cited supra, this note, and Slochower v. Board of Higher Education, 350 U.S. 551 (1956) ; Wieman v. Updegrafi, 344 U.S. 183 (1952).

${ }^{108}$ (1) Stephenson v. Binford, 287 U.S. 251 (1932) ; Fox River Co. v. R.R. Comm'n, 274 U.S. 651 (1927); Packard v. Banton, 264 U.S. 140 (1924); Oceanic Steam Navigation Co. 
In order to resolve this apparent conflict in the cases it has been suggested that such conditions should not be held invalid when they are "germane" to a purpose which the government could otherwise accomplish by withholding the privilege of carrying on the activity. ${ }^{109}$ This standard, however, is too

v. Stranahan, 214 U.S. 320 (1909); Hammond Packing Co. v. Arkansas, 212 U.S. 322 (1909) ; Atkin v. Kansas, 191 U.S. 207 (1903) ; Pullman Co. v. Adams, 189 U.S. 420 (1903); Davis v. Massachusetts, 167 U.S. 43 (1897) ; Horn Silver Mining Co. v. New York, 143 U.S. 305 (1892) ; Philadelphia Fire Ass'n v. New York, 119 U.S. 110 (1886), and other cases collected in Hale, Unconstitutional Conditions and Constitutional Rights, 35 Col. L. Rev. 321 (1935) ; Merrill, Unconstitutional Conditions, 77 U. of Pa. L. Rev. 879 (1929). Some of the cases cited in these articles which seem to uphold "unconstitutional conditions" are, in fact, cases where the limitation imposed by the condition would probably have been valid as a direct regulation and thus did not violate any constitutional rights. Thus, in Stephenson v. Binford, supra, where the state as a condition of using its highways required a trucking company doing business as a private, contract carrier to charge certain minimum freight rates, the decision of the Supreme Court upholding the condition is really defensible because the condition did not in fact infringe any constitutional rights of the trucking company (see Nebbia v. New York, 291 U.S. 502, at 536 [1934]), rather than on the court's tenuous reasoning that the state could impose any condition it chose upon the use of its highways. See also Packard v. Banton, 264 U.S. 140 (1924) ; Oceanic Steam Navigation Co. v. Stranahan, 214 U.S. 320 (1909); Atkin v. Kansas, 191 U.S. 207 (1903). In other of such cases the condition imposed is really a "quid pro quo" to compensate the state for the value of the privilege conferred. Fox River Co. v. R.R. Comm'n, 274 U.S. 651 (1927); Pullman Co. v. Adams, 189 U.S. 420 (1903); Horn Silver Mining Co. v. New York, 143 U.S. 305 (1892); Philadelphia Fire Ass'n v. New York, 119 U.S. 110 (1886). See Hanover Fire Ins. Co. v. Harding, 272 U.S. 494, 510-11 (1926).

(2) Ule v. State, 208 Ind. 255, 194 N.E. 140 (1935); State v. Razey, 129 Kan. 328, 282 Pac. 755 (1929); People v. Rosenheimer, 209 N.Y. 115, 102 N.E. 530 (1913), hold that criminal statutes requiring motorists to give their name, address, and license number when involved in an accident do not violate the self-incrimination privilege because the regulation is so necessary to control highway accidents that a motorist may be required to this extent to waive the self-incrimination privilege as a condition of being permitted to operate an automobile on the public highways. Cf. Commonwealth v. Joyce, 326 Mass. 751, 97 N.E. 2d 192 (1951); Ex parte Kneedler, 243 Mo. 632, 147 S.W. 983 (1912), holding such statutes do not violate the self-incrimination privilege on the dubious ground that the possibility of incrimination from the information required is too remote.

(3) Cases cited note 118 infra, upholding conditions limiting constitutional rights of public employees.

(4) Adler v. Board of Education, 342 U.S. 485 (1952) (discussed note 118 infra); Garner v. Los Angeles Board, 341 U.S. 716 (1951) (discussed note 118 infra); American Communications Ass'n v. Douds, 339 U.S. 382 (1950) (condition requiring officers of all unions desiring recognition under the Labor Management Relations Act to file non-Communist affidavits upheld). Query whether the conditions in these cases are limitations on constitutional rights in light of Dennis v. United States, 341 U.S. 494 (1951). Cf. Gerende v. Election Board, 341 U.S. 56 (1951).

(5) United States v. Field, 193 F.2d 92 (C.A. 2d, 1951) (persons providing bail for the release of prisoners held to waive their self-incrimination privilege by contractually undertaking to supply all information they possess relating to the whereabouts of such prisoners).

See also: Shapiro v. United States, 335 U.S. 1 (1948); Bowles v. Amato, 60 F.Supp. 361 (D. Colo., 1945); State v. Davis, 108 Mo. 666, 18 S.W. 894 (1892), holding that legislation requiring the keeping of specified records in connection with certain regulated activities and their production in court does not violate the self-incrimination privilege because such records are, in effect, public records to which the privilege does not apply.

${ }^{109}$ Hale, op. cit. supra note 108 , at 352,357 . See also Denying the Privilege against SelfIncrimination to Public Officers, 64 Harv. L. Rev. 987, 992 (1951). 
broad to provide adequate protection for constitutional rights. Thus: (1) For the purpose of maintaining the roads in good condition, a state may forbid their use by vehicles over a certain size, ${ }^{110}$ yet a condition to the operation of such vehicles requiring the owners thereof to spend one day a week working on the roads, while "germane" to such purpose, would doubtless be invalid. (2) A state may exclude foreign corporations from carrying on an intrastate business, for the purpose of preventing such corporations from doing business in the state without paying a tax for that privilege commensurate with the tax paid by domestic corporations, ${ }^{111}$ but if a foreign corporation were required as a condition of doing business in the state to pay a tax on property outside the state, such a condition would be unconstitutional, 112 even though the amount of the tax imposed was commensurate with that paid by domestic corporations and the condition was thus "germane" to the purpose. (3) A state may withhold the use of a school building as a public meeting place for the purpose of preventing any persons from meeting on the school premises to plan and instigate the immediate forcible overthrow of the government, but it has been held that a condition requiring the execution of an affidavit by all persons desiring to hold a meeting in a school stating they do not advocate or belong to any organization advocating the violent overthrow of the government is invalid as a prior restraint on freedom of speech, ${ }^{113}$ although such a condition might well be considered "germane" to said purpose. (4) Congress may entirely exclude from the federal courts cases in which the claim is less than a specified amount in order to prevent congestion in the calendars of those courts, but a requirement that parties with claims below that amount must waive the right to a jury trial as a condition of litigating in the federal courts, while "germane" to the purpose of preventing congested calendars, would be of questionable validity.

Although a government may have the power to withhold entirely the privilege of carrying on certain activities, it may not be arbitrary or discriminatory in the exercise of that power ${ }^{114}$ and to be valid a condition to the

${ }^{110}$ See Stephenson v. Binford, 287 U.S. 251 (1932).

${ }^{111}$ Baltic Mining Co. v. Massachusetts, 231 U.S. 68 (1913) ; Horn Silver Mining Co. v. New York, 143 U.S. 305, 317 (1892); Philadelphia Fire Ass'n v. New York, 119 U.S. 110 (1886); and cases collected in 51 Am. Jur., Taxation 762-63, 770-71 (1944).

${ }^{112}$ Looney v. Crane Co., 245 U.S. 178 (1917) ; Western Union Telegraph Co. v. Kansas, 216 U.S. 1 (1910); Pullman Co. v. Kansas ex rel. Coleman, 216 U.S. 56 (1910), and cases collected in 51 Am. Jur., Taxation 767 (1944).

${ }^{112}$ Danskin v. San Diego School District, 28 Cal.2d 536, 171 P.2d 885 (1946).

11' Missouri ex rel. Gaines v. Canada, 305 U.S. 337, 349 (1938); Wieman v. Updegraff, 344 U.S. 183 (1952) ; Frost Trucking Co. v. R.R. Comm'n, 271 U.S. 583, 593-94 (1926); Terral v. Burke Constr. Co., 257 U.S. 529, 532-33 (1922); Danskin v. San Diego School District, 28 Cal.2d 536, 545, 171 P.2d 885, 891 (1946). See Jamison v. Texas, 318 U.S. 413, 415-16 (1943) ; Hague v. C.I.O., 307 U.S. 496, 514-16 (1938); Marsh v. Alabama, 326 U.S. 501 (1946); Hannegan v. Esquire Inc., 327 U.S. 146 (1946). See also Hale, op. cit. supra note 108 , at 322 . 
carrying on of such activities must be reasonable. ${ }^{115}$ A limitation on a constitutional right imposed as a condition of carrying on a lawful activity should therefore be upheld only if: (a) the activity is a privilege conferred by the government and subject to governmental regulation and control, (b) there is a substantial danger that the activity will be carried on in a manner harmful to the public interest, and (c) there is no reasonable method of controlling such harmful conduct without thus limiting a constitutional right.116 This narrower standard would afford greater protection against abrogation of constitutional guarantees, without foreclosing the utilization of conditions affecting constitutional rights in exceptional circumstances. ${ }^{117}$

With regard to the specific problem of conditions which restrict the constitutional rights of public employees, the courts have held that a public employer may sometimes validly impose upon its employees a condition limiting a constitutional right,-for example, a restriction on their political activities. ${ }^{118}$ Such a limitation may be imposed, however, only if the exercise of

${ }^{115}$ Cases cited at note 107 supra.

${ }^{110}$ If the activity consists of the dissemination of ideas or beliefs which do not create a clear and imminent danger of socially harmful conduct such activity is not a privilege conferred by the government but a constitutional right. The particular method of carrying on the activity may be subject to reasonable governmental regulation (e.g., distribution of handbills, door to door canvassing, use of sound trucks, use of school buildings), but a condition to the use of these regulated methods is unconstitutional if it imposes a prior censorship upon such ideas or beliefs. Saia v. People, 334 U.S. 558, 562-63 (1948) ; Cantwell v. Connecticut, 310 U.S. 296, 305 (1940) ; Schneider v. State, 308 U.S. 147, 163 (1939); Hague v. C.T.O., 307 U.S. 496, 515-16 (1939) ; Lovell v. Griffin, 303 U.S. 444 (1938) ; Danskin v. San Diego School District, 28 Cal.2d 536, 548, 171 P.2d 885, 891 (1946). See Thomas v. Collins, 323 U.S. 516, 540 (1945). Cf. Kovacs v. Cooper, 336 U.S. 77 (1949); Cox v. New Hampshire, 312 U.S. 569 (1941). These cases point out that in order to control the mechanics of such methods of dissemination it is possible to enact reasonable regulations which do not invade constitutional rights.

${ }^{112}$ See, for example, Ule v. State, 208 Ind. 255, 194 N.E. 140 (1935) ; Kansas v. Razey, 129 Kan. 328, 282 Pac. 755 (1929) ; People v. Rosenheimer, 209 N.Y. 115, 102 N.E. 530 (1913), upholding criminal statutes requiring motorists to give their name, address, and license number, when involved in an accident, as a valid condition of operating an automobile.

${ }^{118}$ United Public Workers v. Mitchell, 330 U.S. 75 (1947); Ex parte Curtis, 106 U.S. 371 (1882); McAuliffe v. New Bedford, 155 Mass. 216, 29 N.E. 517 (1892) ; McCrory v. Philadelphia, $345 \mathrm{~Pa} .154,27$ A.2d 55 (1942); State ex rel. Baldwin v. Strain, 152 Neb. 763, 42 N.W.2d 796 (1950) ; People ex rel. Clifford v. Scannell, 74 App.Div. 406, 77 N.Y.Supp. 704 (1902).

See Adler v. Board of Education, 342 U.S. 485 (1952), and Garner v. Los Angeles Board, 341 U.S. 716 (1951), upholding statutes requiring discharge of public employees advocating or belonging to organizations advocating the overthrow of the government by force, violence or unlawful means. But query whether such statutes involved a limitation on constitutional rights in light of Dennis v. United States, 341 U.S. 494 (1951). Public employees running for office: State ex rel. Duren v. Patterson, 234 Minn. 432, 48 N.W.2d 574 (1951); School Board of East Chicago v. Sigler, 219 Ind. 9, 36 N.E.2d 760 (1941). Restrictions on organization and strikes by public employees: City of Detroit v. Division 26 of Amalgamated Ass'n, 332 Mich. 237, 51 N.W.2d 228 (1952) ; Norwalk Teachers Ass'n v. Board of Education, 138 Conn. 269, 83 A.2d 482 (1951) ; Perez v. Board of Police Comm'rs, 78 Cal. App.2d 638, 178 P.2d 537 (1947); King v. Priest, 357 Mo. 68, 206 S.W.2d 547 (1947). 
the constitutional right would substantially interfere with the proper performance of the employee's duties. ${ }^{119}$ In that event, a condition of employment limiting the exercise of the right may provide the only reasonable method of control.

Whether a condition of employment limiting the constitutional rights of a public employee is unconstitutional or valid should, therefore, depend upon the function of the particular employee and the extent to which the limitation is necessary to insure effective performance of the function. ${ }^{220}$

The validity of a state-imposed condition requiring public employees to refrain from exercising their self-incrimination privilege will ordinarily be determined initially by a state court. Since the Supreme Court has held that the self-incrimination provision of the Fifth Amendment is not imposed upon the states by the Fourteenth Amendment, no federal question is raised by a state's refusal to give effect to the self-incrimination privilege or by a state's restriction of the privilege under its own constitution. ${ }^{121}$ Nevertheless, if a state court upholds the discharge of a state employee for exercising his privilege against self-incrimination, several federal questions may be presented justifying review by the United States Supreme Court.

(1) If the employee has been discharged for asserting the privilege before a federal tribunal or committee, the state may have abridged a privilege or immunity of a citizen of the United States in violation of the Fourteenth Amendment ${ }^{122}$ and may have interfered with the operation of the Fifth Amendment within its applicable sphere in violation of the supremacy clause of the Constitution. ${ }^{123}$ Although under Twining v. New Jersey ${ }^{124}$ the Fifth and Fourteenth Amendments do not confer upon citizens of the United States a privilege or immunity against self-incrimination before state agencies, the Fifth Amendment does confer upon citizens of the United States a right to assert the privilege before federal agencies, which right is beyond the reach of state control. ${ }^{125}$ However, since the federal government may, as a

\footnotetext{
${ }^{119}$ United Public Workers v. Mitchell, 330 U.S. 75, 97-101 (1947) ; Ex parte Curtis, 106 U.S. 371,373 (1882); and cases cited note 147 infra.

${ }^{120}$ See 101 U. of Pa. L. Rev., op. cit. supra note 83, at 1203.

121 Twining v. New Jersey, 211 U.S. 78 (1908); Palko v. Connecticut, 302 U.S. 319 (1937) ; Adamson v. California, 332 U.S. 46 (1947). But see Adamson v. California, supra, at 68, 124 (1947) (dissents); Regan v. New York, 349 U.S. 58, 65, 66 (1955) (concurrence and dissent). Cf. State v. Height, 117 Iowa 650, 91 N.W. 935 (1902); Koenck v. Cooney, 244 Iowa 153, 55 N.W.2d 269 (1952).

120 U.S. Const. Amend. 14, §1. In Slochower v. Board of Higher Education, 350 U.S. 551, 555,567 (1956), the court expressly reserved this question.

${ }^{203}$ U.S. Const. Art. 6, \$2. Consult Horowitz, op. cit. supra note 101, at 273.

124 211 U.S. 78 (1908).

${ }^{205}$ See Hague v. C.I.O., 307 U.S. 496 (1939). See also Terral v. Burke Constr. Co., 257 U.S. 529 (1922); Barron v. Burnside, 121 U.S. 186 (1887); Security Mutual Life Ins. Co. v. Prewitt, 202 U.S. 246, 258 (1906) (dissent).
} 
condition of employment, limit the exercise by its employees of a federal constitutional right ${ }^{126}$ when the exercise of the right would substantially interfere with their duties, perhaps a state may likewise impose a condition of employment which limits the exercise by its employees of a federal constitutional right if the exercise of the federal right would substantially interfere with the performance of their duties.

(2) The discharge of public employees for exercising the self-incrimination privilege conferred by a state constitution upon all persons in the state may be so discriminatory as to deny such employees the equal protection of the law in violation of the Fourteenth Amendment, unless there are reasonable grounds for placing them in a separate classification with regard to exercise of the privilege. ${ }^{127}$

(3) If the discharge of a state employee is arbitrary, unreasonable or discriminatory, it will violate the due process clause of the Fourteenth Amendment. ${ }^{128}$ Since no adverse inference is to be drawn from the exercise of the self-incrimination privilege, the discharge of a public employee solely for asserting the privilege may deprive him of due process of law unless there is a reasonable basis for the discharge. ${ }^{12 \theta}$

Thus, the determination of all these constitutional issues will turn upon the extent to which the exercise of the privilege interferes with the proper performance of the employee's duties. This test should also be applied in determining the validity, under the self-incrimination and due process clauses of the Fifth Amendment, of a condition restricting the assertion of the privilege if imposed by the federal government upon its employees. ${ }^{130}$

The issue as to the validity of such conditions of employment has recently been brought into sharp focus by cases dealing with the discharge of public school teachers. Prior to the decision in Slochower v. Board of Higher Education, ${ }^{131}$ the question of whether public school teachers could be required to refrain from exercising their constitutional privilege against self-incrimination

${ }^{120}$ I.e., the right to engage in political activities. See cases cited note 118 supra.

${ }^{127}$ U.S. Const. Amend. 14, $\$ 1$. See Griffin v. Illinois, 351 U.S. 12, 20 et seq. (1956) ; Missouri ex rel. Gaines v. Canada, 205 U.S. 337, 349 (1938) ; Regan v. New York, 349 U.S. 58, 65 (1955) (concurrence); 101 U. of Pa. L. Rev., op. cit. supra note 83, at 1198-99.

158 U.S. Const. Amend. 14, $\$ 1$. Slochower v. Board of Higher Education, 350 U.S. 551 (1956); Wieman v. Updegraff, 344 U.S. 183 (1952).

${ }^{120}$ Cases cited note 128 supra.

${ }^{130}$ See Pfitzinger v. United States Civil Service Comm'n, 96 F.Supp. 1, 2 (D. N.J., 1951). By presidential order, refusal by a federal employee to testify before a congressional committee concerning possible misconduct constitutes grounds for discharge. Exec. Order No. 10491, 3 Code Fed. Regs. 109 (Supp., 1953).

131350 U.S. 551 (1956), modified 351 U.S. 944 (1956). See note 134 infra. 
was presented to the appellate courts of Massachusetts, ${ }^{132}$ California, ${ }^{133}$ and New York. ${ }^{134}$ In each jurisdiction such a condition of employment was held to be valid: in Massachusetts principally on the ground that by asserting the privilege a teacher brings such distrust and suspicion upon himself that his continued employment would tend to destroy public confidence in the public schools; in California on the ground that exercise of the privilege interferes with the teacher's duty to furnish information as to fitness; and in New York on the ground that exercise of the privilege obstructs investigation of the teacher's official conduct.

In the Slochower case, as previously indicated, the Supreme Court refused to permit an inference of incriminating facts to be drawn from the exercise of the privilege by a publicly-employed professor. The Court, however, did not squarely decide the issue as to the validity of a condition of employment requiring publicly-employed school teachers to refrain from exercising the self-incrimination privilege. Its decision that the summary dismissal of the professor without a proper inquiry into his fitness violated due process of law was expressly based on the following factors peculiar to the case: (1) The Senate sub-committee was not investigating the fitness of the professor to hold his position nor the official conduct of any state employee. ${ }^{\mathbf{1 3 5}}$ (2) The

\footnotetext{
${ }^{132}$ Opinion of the Justices, 332 Mass. 759, 127 N.E.2d 663 (1955) ; Faxon v. School Committee of Boston, 331 Mass. 531, 120 N.E.2d 772 (1954).
}

${ }^{153}$ Board of Education v. Eisenberg, 129 Cal.App.2d 732, 277 P.2d 943 (1954), upholding the discharge of a teacher for invoking the privilege before a legislative committee in violation of a school board rule. In Steinmetz v. State Board of Education, 44 Cal.2d 816, 824, 285 P.2d 617, 621 (1955), and Pockman v. Leonard, 39 Cal.2d 676, 687, 249 P.2d 267, 274 (1952), the California Supreme Court upheld, against the attack of two college professors, statutes requiring state employees to take an oath concerning their advocacy of violent overthrow of the government or membership in organizations urging such action and to answer under oath questions relating to such matters upon the order of the agency employing them. Although the self-incrimination privilege was not asserted in either case, the court in brief dicta indicated that teachers could be discharged for invoking the privilege in response to demands for information concerning fitness and loyalty. See also Board of Education v. Wilkinson, 125 Cal.App.2d 100, 270 P.2d 82 (1954). After the Slochower decision the California Supreme Court, in Board of Education v. Mass, 47 Adv. Cal. 501, 304 P.2d 1015 (1957) (discussed in note 175 infra), sustained, as a valid method for determining fitness, a statutory condition that school employees refrain from exercising the privilege before a legislative committee when being questioned about Communist Party membership, advocacy of violent overthrow of the government, or membership in organizations urging such action, but held that a teacher could be dismissed for violating the condition only after a hearing to determine the sufficiency of his reasons for exercising the privilege.

${ }^{234}$ Daninan v. Board of Higher Education, 306 N.Y. 532, 119 N.E.2d 373 (1954) ; Goldway v. Board of Higher Education, 178 N.Y.Misc. 1023, 37 N.Y.S.2d 34 (S.Ct., 1942). In the Daninan case there were a total of fourteen plaintiffs. The United States Supreme Court dismissed the appeal of thirteen of them for want of a properly presented federal question, but allowed the appeal of the fourteenth, Harry Slochower, because the New York Court of Appeals amended its remittitur to state that a federal question had been presented and passed on as to him. Slochower v. Board of Higher Education, 350 U.S. 551, 555 (1956).

${ }^{255}$ Slochower v. Board of Higher Education, 350 U.S. 551, 558 (1956). 
professor had previously answered questions about his activities during the years in question before a state legislative committee and before a faculty board of investigation, so no pertinent information concerning his fitness was withheld from school authorities by his exercise of the privilege. ${ }^{136}$ In this respect, the Court stated, ${ }^{137}$ the case differed from Garner v. Los Angeles Board of Public Works ${ }^{138}$ which upheld the right of a municipality investigating the fitness of its employees to discharge them for failure to execute an affidavit concerning Communist Party membership and an oath concerning advocacy of violent overthrow of the government or membership in organizations urging such action. (3) The automatic discharge did not permit consideration of the fact that the questions which were not answered concerned activities at a remote period of time having little relevance to present fitness or of the fact that the refusal to answer may have been a result of mistake, inadvertence or reliance on legal advice..$^{139}$

Four justices dissented on the grounds that refusal of a teacher to answer questions concerning official conduct or fitness justifies his summary discharge regardless of the fact that he had previously supplied such information to the school authorities. ${ }^{140}$ Three of these justices added the additional ground that a teacher, as a public employee, has a duty to furnish facts pertinent to official inquiries, and this failure to do so can properly be considered by the state to stamp him as unfit to hold an official position. ${ }^{141}$ One justice also reasoned that the state may consider teachers who refuse to answer questions concerning their official conduct to be unfit because their refusal to answer jeopardizes public confidence in the school system..$^{142}$

In light of the particular limitations set forth, the majority opinion appears to hold that a publicly employed teacher cannot be discharged for exercising his self-incrimination privilege when the exercise of the privilege does not result in withholding pertinent information as to his fitness for the position. Since, however, every question to which the self-incrimination privilege may be asserted must concern matters relating to possible criminal activity on the part of the witness, it will be only in an exceptional situation, such as existed in the Slochower case, that the exercise of the privilege will not result in withholding pertinent information as to fitness.

Did the Court also intend to imply that a teacher can be discharged for exercising his privilege if the exercise of the privilege does result in withholding pertinent information as to his fitness? The pointed reference in the

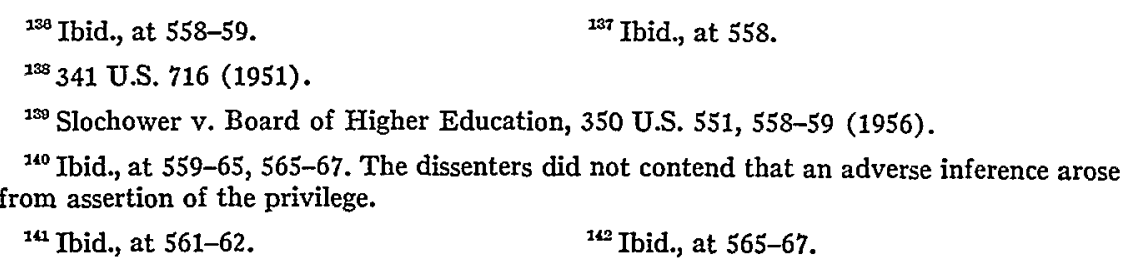


opinion to Garner v. Board of Public Works, ${ }^{143}$ which sustained the right of a public employer to discharge employees for withholding information bearing upon their fitness, may be considered as an implication to this effect. ${ }^{144}$ The Garner case, however, contains not one word about the privilege against selfincrimination. The employees there involved apparently made no attempt to invoke that privilege, and the court decided only that the municipal ordinance, requiring an oath as to knowingly disloyal activities and an affidavit as to Communist Party membership, was neither ex post facto legislation, a bill of attainder nor an infringement on freedom of speech and assembly. It seems unlikely that the majority in Slochower intended to resolve such a farreaching question by reference to a case not really in point. It would therefore appear that the decision is confined to the narrow facts before the court, leaving open the broader issue.

As heretofore stated, the validity of a condition of employment limiting the exercise by a public employee of his self-incrimination privilege should depend upon the extent to which the exercise of the privilege interferes with the performance of his duties. Since the functions of public employees vary greatly, such a condition of employment might reasonably be applied to one type of employee but not to another. ${ }^{145}$ Therefore, in considering the discharge of public school teachers for asserting the privilege, the nature of a school teacher's duties should be examined to determine whether the act of exercising the privilege would interfere with their effective performance.

The courts, however, have not concerned themselves to any great extent with an examination of the relationship between a teacher's duty and the assertion of the privilege. ${ }^{146}$ Several cases have upheld the dismissal of police officers for exercising the self-incrimination privilege, ${ }^{147}$ and on their authority

${ }^{263} 341$ U.S. 716 (1951).

${ }^{14}$ See also Black v. Cutter Laboratories, 351 U.S. 292, 297 (1956).

${ }^{115}$ Consult 101 U. of Pa. L. Rev., op. cit. supra note 83, at 1203. But see Koral v. Board of Education, 197 N.Y.Misc. 221, 94 N.Y.S.2d 378 (S.Ct., 1950).

${ }^{140}$ The Slochower case, for example, makes no attempt to analyze this relationship.

${ }^{14}$ Drury v. Hurley, 339 Ill.App. 33, 88 N.E.2d 728 (1949); Canteline v. McClellan, 282 N.Y. 166, 25 N.E.2d 972 (1940) (dismissal authorized by constitutional provision) ; Christal v. Police Comm'r of San Francisco, 33 Cal.App.2d 564, 92 P.2d 416 (1939) ; Scholl v. Bell, 125 Ky. 750, 102 S.W. 248 (1907). Cf. Souder v. Philadelphia, 305 Pa. 1, 156 Atl. 245 (1931) (no claim of privilege) ; State ex rel. Christian v. Barry, 123 Ohio St. 458,175 N.E. 855 (1931) ; Garvin v. Chambers, 195 Cal. 212, 224-26, 232 Pac. 696, 701 (1924). See also McAuliffe v. New Bedford, 155 Mass. 216, 220, 29 N.E. 517, 517 (1892) (Holmes, J.): "The petitioner may have a constitutional right to talk politics, but he has no constitutional right to be a policeman." It is to be noted that these cases recognize the right of a policeman to assert the privilege although he may be discharged for doing so. They do not hold that a policeman waives his right to assert the privilege by entering upon his employment. Cf. Ule v. State, 208 Ind. 255, 194 N.E. 140 (1935) ; State v. Razey, 129 Kan. 328, 282 Pac. 755 (1929) ; People v. Rosenheimer, 209 N.Y. 115, 102 N.E. 530 (1913) ; United States v. Field, 193 F.2d 92 (C.A. 2d, 1951). 
the Massachusetts, ${ }^{148}$ California, ${ }^{149}$ and New York ${ }^{150}$ courts concluded that such a condition of employment could likewise be validly imposed on public school teachers, without considering the difference in function between police officers and school teachers.

A policeman is directly engaged in detecting and reporting criminal acts. The effective performance of such duties requires that he disclose all information known to him concerning the commission of crimes. ${ }^{151} \mathrm{~A}$ requirement that he not withhold such information by the exercise of his self-incrimination privilege may be considered so necessary to insure his proper functioning as a policeman as to be a valid condition of his employment. ${ }^{152}$ The requirement that a street sweeper refrain from asserting his self-incrimination privilege, on the other hand, may have so little bearing upon the proper performance of his duties as to make it an invalid condition of his employment.

A public school teacher, among other things, must be qualified by education and experience to present a particular subject to his students; a teacher must be physically capable of presenting the subject; a teacher must be a lawabiding person of good moral character; and a teacher must be free from any commitments which would cause him to distort or falsify the subject being presented or to attempt to indoctrinate his students with concepts outside the scope of that subject. ${ }^{153}$ In the absence of any inference of wrongdoing the exercise of the privilege by a teacher is not evidence of lack of qualification, nor would it seem to interfere with the proper execution of his functions as

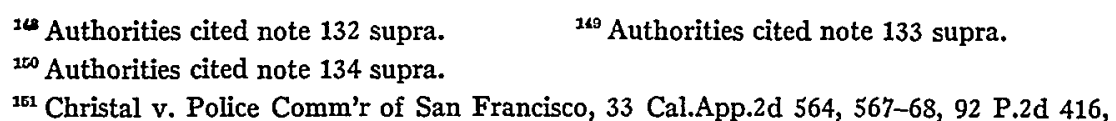
419 (1939): "Among the duties of police officers are those of preventing the commission of crime, of assisting in its detection, and of disclosing all information known to them which may lead to the apprehension and punishment of those who have transgressed our laws. When police officers acquire knowledge of facts which will tend to incriminate any person, it is their duty to disclose such facts to their superiors and to testify freely concerning such facts when called upon to do so before any duly constituted court or grand jury. It is for the performance of these duties that police officers are commissioned and paid by the community, and it is a violation of said duties for any police officer to refuse to disclose pertinent facts within his knowledge even though such disclosure may show, or tend to show, that he himself has engaged in criminal activities."

${ }^{152}$ Ibid. In In re Holland, 377 Il. 346, 357-58, 36 N.E.2d 543, 548-49 (1941), the Illinois Supreme Court, holding a lawyer could not be disbarred for asserting the self-incrimination privilege, distinguished the policeman cases as follows: "In such cases it was recognized that the officer was especially charged with the duty to prevent crime and to disclose any evidence that would assist in the apprehension of criminals.... It can scarcely be said that the duty resting on a lawyer to assist in investigation of crime, a duty with which he is generally though not specifically charged, as is a policeman, outweighs, when considered from the standpoint of legal ethics, his moral as well as legal right to claim the constitutional privilege. ..." See 101 U. of Pa. L. Rev., op. cit. supra note 83, at 1203. Cf. State ex rel. Christian v. Barry, 123 Obio St. 458, 175 N.E. 855 (1931).

${ }^{153}$ Consult Academic Freedom and National Security, 42 Am. Ass'n of Univ. Prof. Bull. 49, 57-58 (1956) ; 39 Am. Ass'n of Univ. Prof. Bull. 92-93 (1953). 
reflected by the foregoing requirements. ${ }^{154}$ Prima facie, there appears to be no essential connection between the effective performance of a teacher's duties and the surrender of the privilege. ${ }^{155}$

The Massachusetts court in Faxon v. School Committee of Boston ${ }^{\mathbf{1 5 6}}$ and one dissenter in the Slochower case ${ }^{157}$ attempt to supply this essential connection by arguing that continued employment of a teacher who has asserted the privilege tends to destroy public confidence in the public schools. Predicting the public's reaction to a particular situation, however, may be as difficult as forecasting a political election. While some persons may lose confidence in a school that continues to employ a teacher who has asserted the self-incrimination privilege, others may lose confidence in a school that summarily discharges such a teacher. Judicial determination of the power of a state to restrict the constitutional rights of its employees should not turn upon how the public would vote on the matter.

If public opinion could provide a test for determining the validity of such a condition of employment, the court would have to evaluate the reasonableness of that opinion. Constitutional rights should not be restricted on the basis of a court's conclusion that the public will arbitrarily or capriciously respond in an adverse manner to the exercise of such rights. ${ }^{158}$ Since an inference of wrongdoing cannot reasonably be drawn from the exercise by a witness of the self-incrimination privilege, the public would not be reasonably justified in losing confidence in the public schools as the result of continued employment of a teacher who had exercised the privilege unless the exercise

\footnotetext{
${ }^{154}$ Consult Academic Freedom and National Security, op. cit. supra note 153, at 57-58, 100 ; Resolutions, 39 Am. Ass'n of Univ. Prof. Bull. 90, 95-96 (1953) ; Byse, op. cit. supra note 83, at 879; Chaffee, op. cit. supra note 57, at 230-31. Cf. Rights and Responsibilities of Universities and their Faculties, Ass'n of Am. Universities, Mar. 24, 1953, quoted in Slochower v. Board of Higher Education, 350 U.S. 551, 564 (1956) (dissent).

${ }^{100}$ For situations where the exercise of a right, restricted by the terms of employment, interfered with the effective performance of a teacher's duties see: Joyce v. Board of Education, 325 Ill.App. 543, 60 N.E.2d 431 (1945) (statements in the classroom praising Hitler during time of war and writing a letter congratulating a student on evading the draft); School Board of East Chicago v. Sigler, 219 Ind. 9, 36 N.E.2d 760 (1941) (running for office); Board of Education of Eureka v. Jewett, 21 Cal.App.2d 64, 68 P.2d 404 (1937) (statements in the classroom that it was silly to salute the American flag, that Russia had the best government in the world and the United States had the worst, that the United States was the aggressor in every war and a bully, and that if the United States became involved in another war he would have nothing to do with it).

${ }^{158} 331$ Mass. 531, 120 N.E.2d 772 (1954).

${ }^{157} 350$ U.S. 551, 565-67 (1956).

${ }^{158}$ In re Holland, 377 Ml. 346, 353, 36 N.E.2d 543, 546-47 (1941): "The late Mr. Justice Cardozo in his Paradoxes on Legal Science, page 48, makes the statement that where government makes a declaration of right, such is 'the admission by organized society that the claim is justified from the public point of view.' That principle may be applied in a case of this kind. The right given by the constitution being legal, is as well a moral right, since the public point of view can scarcely be said to include that which is not moral." The rights of a private employee in this regard may be somewhat different. See note 178 infra.
} 
of the privilege would substantially interfere with the performance of the teacher's duties. Therefore, the interpolation of the issue of public opinion into the problem does not assist in its resolution; the court must still decide the question on the basis of the relationship between the particular limitation and the function of the particular employee.

Nor is the essential connection between a teacher's functions and the surrender of the privilege supplied by the argument of three of the dissenters in the Slochower case that teachers as public employees are under a duty to reveal whatever pertinent information they possess to official investigating bodies. ${ }^{159}$

Every person has a duty to furnish pertinent information to official investigators. That duty does not extend to answering questions concerning matters of an incriminating nature. ${ }^{160}$ Nothing in the teaching function imposes upon teachers a duty to forego the self-incrimination privilege in furnishing such information. ${ }^{161}$ It is true that teachers should set an example of lawabiding conduct to their students, but the exercise of a constitutional right is not an unlawful or immoral act.162

The argument that teachers are under a duty to reveal information as to their own fitness, including information as to their official conduct, comes closest to providing an essential connection between a teacher's functions and surrender of the privilege. ${ }^{163} \mathrm{~A}$ requirement that teachers reveal such information under oath, however, does not relate to an integral part of the teaching function; rather its purpose is to assist the school authorities in investigating a teacher's qualifications and competency. School authorities, of course,

${ }^{150} 350$ U.S. 551, 561-62 (1956).

160 " [T] The innocent and guilty alike have a right of recourse to the Fifth Amendment. And if the innocent man has a clearly defined right to such recourse it is inconceivable that he could simultaneously have a duty not to have recourse, since rights and duties are correlative. Nor can it be argued that non-recourse is a duty of piety rather than justice. If such an opinion were binding and all innocent men waived their rights to the protection of the Fifth Amendment, the purpose of the law would be defeated and the common welfare of the nation would suffer rather than prosper." Fearon, Congressional Investigations and Moral Theology, The Commonweal 497, 499 (Feb. 19, 1954).

${ }^{101}$ Consult authorities cited notes 170 and 172 infra.

${ }_{162}$ "Unless the circumstances surrounding him or duties placed upon him are of such character as to require, in honesty and good conscience, that he waive the right, we are unable to see wherein it can be said that an individual, be he judge, lawyer, or layman, is either legally or morally guilty of a wrong should he claim the right [to exercise the privilege]." In re Holland, 377 Mll. 346, 357, 36 N.E.2d 543, 548 (1941). See also note 158 supra; Byse, op. cit. supra note 83.

${ }^{103}$ Slochower v. Board of Higher Education, 350 U.S. 551, 559-67 (1956) (dissents); Board of Education v. Mass, 47 Adv.Cal. 501, 304 P.2d 1015 (1957); Board of Education v. Eisenberg, 129 Cal.App.2d 732, 277 P.2d 943 (1954); Goldway v. Board of Higher Education, 178 N.Y.Misc. 1023, 37 N.Y.S.2d 34 (S.Ct., 1942). See Steinmetz v. State Board of Education, 44 Cal.2d 816, 824, 285 P.2d 617, 621 (1955). Cf. Adler v. Board of Education, 342 U.S. 485 (1952); Garner v. Los Angeles Board, 341 U.S. 716 (1951). Consult 64 Harv. L. Rev., op. cit. supra note 109. 
have the right to investigate the fitness of teachers and in doing so to ask the teachers pertinent questions concerning their activities and conduct. ${ }^{164}$ But the refusal by a teacher to answer such questions on the grounds of selfincrimination should not be grounds for discharge unless the exercise of the privilege precludes the school authorities from effectively investigating the teacher's fitness. An exercise of the privilege is not likely to have such an inhibiting effect. On the contrary it would probably stimulate a careful investigation of the teacher's fitness and a review of all relevant evidence relating thereto. ${ }^{165}$

It is true that a condition requiring teachers to answer all questions concerning their conduct, on or off the job, would have some tendency to inhibit undesirable activities on their part, just as abolition of the self-incrimination privilege would have some tendency to inhibit undesirable behavior on the part of all persons. That condition, however, is not the only reasonable method of controlling such activities. Effective means for their prevention and detection can be provided, without constitutional infringement, by adequate measures for supervision, investigation and discharge for cause after hearing.

A hearing in which all available evidence is carefully weighed provides a more effective method of evaluating fitness than an investigation confined to questioning the person being investigated and is more in accord with American concepts of proper procedure. ${ }^{166}$ The Supreme Court has recognized the importance of a fair hearing when the fitness of a public employee is under consideration, ${ }^{167}$ and the discharge of a teacher or other public employee ordinarily occurs only after a full hearing wherein the alleged unfitness is substantiated by specific evidence. ${ }^{168}$ Such procedure is adhered to in cases involving allegations of disloyalty. ${ }^{169}$ Summary dismissal for exercise of the

${ }^{104}$ Adler v. Board of Education, 342 U.S. 485 (1952); Garner v. Los Angeles Board, 341 U.S. 716 (1951) ; Steinmetz v. State Board of Education, 44 Cal.2d 816, 285 P.2d 617 (1955) ; Pockman v. Leonard, 39 Cal.2d 676, 249 P.2d 267 (1952); Board of Education v. Wilkinson, 125 Cal.App.2d 100, 270 P.2d 82 (1954); Board of Education v. Beilan, 386 Pa. 82,125 A.2d 327 (1956).

${ }^{10-}$ Academic Freedom and National Security, op. cit. supra note 153, at 58-59.

${ }^{100}$ See Sheiner v. State, 82 So.2d 657, 665 (Fla., 1955); Board of Education v. Beilan, $386 \mathrm{~Pa} .82,110-17,125$ A.2d 327, 340-43 (1956) (dissent); Byse, op. cit. supra note 83, at \$78-83.

${ }^{197}$ Slochower v. Board of Higher Education, 350 U.S. 551, 559 (1956). See Adler v. Board of Education, 342 U.S. 485 (1952). Cf. Board of Education v. Mass, 47 Adv. Cal. 501, 304 P.2d 1015 (1957), discussed at note 175 infra.

${ }^{10 \%}$ See Board of Education v. Swan, 41 Cal.2d 546, 261 P.2d 261 (1953) ; Joyce v. Board of Education of Chicago, 325 Ill.App. 543, 60 N.E.2d 431 (1945) ; State v. Turner, 155 Fla. 270, 19 So.2d 832 (1944); Wilmerding School District Bd. v. Gillies, 343 Pa. 382, 23 A.2d 447 (1942); Souder v. Philadelphia, 305 Pa. 1, 156 Atl. 245 (1931); Garvin v. Chambers, 195 Cal. 212, 225, 232 Pac. 696, 701 (1924). See also Cole v. Young, 351 U.S. 536 (1956), and authorities cited at note 170 infra.

${ }^{165}$ Cole v. Young, 351 U.S. 536 (1956) ; see Adler v. Board of Education, 342 U.S. 485 (1952); Joyce v. Board of Education of Chicago, 325 Ill.App. 543, 60 N.E.2d 431 (1945); Wilmerding School District Bd. v. Gillies, 343 Pa. 382, 23 A.2d 447 (1942). 
constitutional privilege against self-incrimination is a poor substitute for this time-tested method of hearing and evaluating the evidence. ${ }^{170}$

In an analogous situation involving investigations of attorneys for unfitness to practice law, a number of courts have held that assertion by an attorney of the self-incrimination privilege does not justify disciplinary action against him. ${ }^{171}$ While it is true that attorneys are not public employees, they nevertheless are subject to strict governmental control and are permitted to practice only if they comply with reasonable conditions imposed by the state. The fitness of attorneys to practice law approaches in importance the fitness of public employees to perform the duties of their employment, and public authorities are free to investigate the fitness of attorneys at any time. Attorneys may not, however, be required as a condition of practicing law to refrain from exercising their self-incrimination privilege. ${ }^{172}$ Investigations are not seriously impeded by an assertion of the privilege; disciplinary action may still be imposed on the basis of independent evidence of wrongdoing presented at a full and fair hearing. ${ }^{173}$ In the absence of such independent evidence of wrongdoing, disbarment of an attorney for exercising the privilege has been held to violate procedural due process of law. ${ }^{174}$

${ }^{170}$ Consult Academic Freedom and National Security, supra note 153, at 57-60, 100; Resolutions, op. cit. supra note 154, at 91-96; Barth, Universities and Political Authority, 39 Am. Ass'n of Univ. Prof. Bull. 5, 9-11 (1953) ; Chaffee, op. cit. supra note 57, at 229-34.

${ }^{271}$ Sheiner v. State, 82 So.2d 657 (Fla., 1955); In re Holland, 377 Ill. 346, 36 N.E.2d 543 (1941) ; Matter of Grae, 282 N.Y. 428, 26 N.E.2d 963 (1940); Matter of Kaffenburg, 188 N.Y. 49, 80 N.E. 570 (1907). See Ex parte Marshall, 165 Miss. 523, 147 So. 791 (1933). Cf. In re Antastaplo, 3 Ill.2d 471, 121 N.E.2d 826 (1954) (no claim of privilege); Matter of Rouss, 221 N.Y. 81,116 N.E. 782 (1917) (scope of immunity statute).

Several cases have upheld disciplinary action against attorneys after exercise of the selfincrimination privilege. Matter of Fenn, 235 Mo.App. 24, 128 S.W.2d 657 (1939); Fish v. State Bar of California, 214 Cal. 215, 4 P.2d 937 (1931); In re Vaughan, 189 Cal. 491, 209 Pac. 353 (1922); In re Wellcome, 23 Mont. 450, 59 Pac. 445 (1899). In every such case, however, there was independent evidence of wrongdoing sufficient to uphold the action taken. See Sheiner v. State, 82 So.2d 657, 665 (Fla., 1955). Since such disciplinary proceedings are not criminal cases, the attorney may be required to testify as a witness. While he may refuse to answer questions of an incriminating nature, if, by thus exercising the privilege, he fails to refute independent, adverse evidence introduced against him, the trier of the fact may infer that such evidence is true in accordance with the rule in civil cases. In re Wellcome, supra; Fish v. State Bar of California, supra; In re Vaughan, supra. Consult discussion at 476 supra. There is no case upholding disciplinary action against an attorney solely on the basis of an exercise of the privilege in the absence of independent, adverse evidence. See Sheiner v. State, supra.

${ }^{172}$ Sheiner v. State, 82 So.2d 657,660 (Fla., 1955): "[W]e do not overlook the contention of the state that there is a distinction between the right of ... the lawyer as such to invoke protection of the Fifth Amendment; that while he may invoke such protection as an individual if he does so as a lawyer he forfeits the privilege to practice law. We know of no warrant for any such distinction. ..."

${ }^{173}$ Authorities cited note 171 supra and note 174 infra.

${ }^{174}$ In Sheiner v. State, 82 So.2d 657, 660-61 (Fla., 1955), the Supreme Court of Florida, in reversing the disbarment of an attorney for exercising the self-incrimination privilege, 
As previously pointed out, school authorities may at any time make proper inquiry into the fitness of teachers and discharge anyone proven to be unfit. As an initial step in such an inquiry the authorities may, if they wish, request teachers to give information under oath concerning activities which have a reasonable bearing on fitness. Those teachers supplying such information in the manner requested may be considered as having established their fitness with regard to such matters. If any teacher refuses to supply such information on grounds of self-incrimination, or if any teacher invokes the privilege while testifying before some official body, the authorities are free to make further inquiry into the fitness of that teacher. Such an inquiry should ordinarily consist of a complete hearing in which all pertinent facts are considered, and a decision against the teacher should be based upon substantial evidence of unfitness apart from the exercise of the privilege. ${ }^{17 \delta}$

stated: "The real controversy here is whether or not due process was accorded appellant in taking from him the privilege to practice law. Did the state prove the charge against appellant by conclusive evidence? ... I do not think the state can abandon proof of charges against an attorney for unprofessional conduct and disbar him on grounds that he challenges and that are not proven." The concurring opinion stated: "The state has charged or alleged certain conduct of appellant to be inimical to the best interests of the profession and his country. Witnesses are apparently available to sustain these allegations. If not, investigative weapons are certainly available to the State Attorney by which a 'case' may be made. ... If the appellant has manifested a want of fidelity to the system of lawful government which he has sworn to uphold and preserve, let it be shown by a 'preponderance of the evidence' in what has come to be known . . . as the American way. . . ." Ibid., at 666.

${ }^{175}$ Consult Academic Freedom and National Security, op. cit. supra note 153, at 58-60, 100; Chaffee, op. cit. supra note 57, at 229-34.

In Slochower v. Board of Higher Education, 350 U.S. 551, 559 (1956), the Court stated: "The State has broad powers in the selection and discharge of its employees, and it may be that proper inquiry would show Slochower's continued employment to be inconsistent with a real interest of the State. But there has been no such inquiry here." (Italics added.) Earlier in the opinion the court pointed out that under the charter provision in question "[n]o consideration is given to such factors as the subject matter of the questions, remoteness of the period to which they are directed, or justification for exercise of the privilege. It matters not whether the plea resulted from mistake, inadvertence or legal advice conscientiously given, whether wisely or unwisely." Ibid., at 558 .

In Board of Education v. Mass, 47 Adv.Cal. 501, 506, 304 P.2d 1015, 1019 (1957), the California Supreme Court interpreted the foregoing language as holding that "a public employee may be dismissed for invoking the privilege against self-incrimination only if, after a full hearing in which he is afforded an opportunity to explain his reasons for claiming the privilege, it is determined that his refusal to answer is sufficient under the circumstances to warrant dismissal." On the basis of that interpretation the California court upheld the constitutionality of a state statute requiring the discharge of school employees who refuse, on any grounds, to answer, before a legislative investigating committee, questions relating to Communist Party membership, advocacy of violent overthrow of the government or membership in organizations urging such action, by construing the statute as requiring a hearing to determine the sufficiency of an employee's reasons for asserting the self-incrimination privilege in response to such questions. In light of the wide variety of psychological motives for asserting the privilege, it is not clear by what standard such motives can be evaluated to determine which are "sufficient" and which are "insufficient" to warrant dismissal of the employee. As stated by the dissenters, who were of the opinion that after 
An investigation of this nature would enable school authorities to detect and remove unfit employees, protect the constitutional rights of such employees and maintain public confidence in the schools. ${ }^{176}$ With such procedures available the assertion by a teacher of his self-incrimination privilege in response to questions concerning matters of fitness would appear to interfere with neither his teaching functions nor an investigation of his fitness to such an extent as to justify his discharge on that basis alone. ${ }^{177}$

If the exercise of the privilege does not interfere with the performance of a teacher's duties and there are other effective methods of investigating his fitness, a state-imposed condition of employment requiring public school teachers to refrain from asserting the self-incrimination privilege guaranteed by the state constitution violates that constitutional provision and is probably unreasonable, arbitrary and discriminatory in violation of the due process and equal protection clauses of the Fourteenth Amendment. If the condition requires teachers to refrain from asserting their privilege under the Fifth Amendment, it probably also violates the privileges and immunities clause of the Fourteenth Amendment and the supremacy clause of Article VI. If the condition is imposed by the federal government on federally employed school teachers, it would appear to violate the self-incrimination and due process provisions of the Fifth Amendment.

For the same reasons, and apart from the rights of a private employer to discharge employees for exercising the privilege, ${ }^{178}$ such a condition of em-

exercising the privilege the employee could properly be discharged without any hearing at all, such a hearing "launches the trial court upon an uncharted course to determine the 'sufficiency' of reasons for defendant's refusal [to answer on grounds of self-incrimination]." Ibid., at 515-16, 1025. The employee cannot be required to state whether one of his motives for exercising the privilege was to avoid revealing incriminating facts, because such a requirement would itself violate the privilege (An admission of the existence of such facts would be available as evidence against him in a criminal prosecution.). If he gives one or more non-incriminating motives for exercising the privilege, such as to protect friends, or to avoid a possible perjury prosecution, or to express his disapproval of the committee, or to forestall an inquiry into political beliefs and opinions, or simply to preserve the effectiveness of the constitutional provision against self-incrimination, how can a tribunal determine that any of such motives are sufficient to justify his discharge? It would appear that any hearing which is held should be for the purpose of examining evidence of activities bearing more directly upon his fitness for his particular employment, such as knowing membership in organizations advocating the overthrow of the government by force and violence.

${ }^{176}$ Byse, op. cit. supra note 83, at 878-83.

177 Authorities cited note 170 supra.

${ }^{178}$ A typical contractual limitation on the right of a private employer to discharge his employees is a provision in an employment contract providing that the employer may discharge the employee only for "just cause" or "good cause." See Horowitz, op. cit. supra note 101, at 270; Black v. Cutter Laboratories, 351 U.S. 292 (1956). If the employee sues for breach of contract when his employer discharges him for exercising the privilege against self-incrimination, the court must decide whether such discharge was for just or good cause under the terms of the contract. Since exercise of the privilege does not give rise to an 
ployment is probably invalid as to any public employee if the exercise of the privilege would not substantially impede the performance of his duties nor preclude an effective investigation of his fitness and conduct.

inference of wrongdoing, it would not seem to constitute good cause for discharge in the absence of proof that it substantially interfered with the performance of the employee's duties or that the actual existence of an unfavorable public reaction, even if unreasonable, adversely affected to a substantial degree the marketability of the employer's product or the efficiency of his business operations. Cf. United Electrical Radio \& M. Workers v. General Electric Co., 127 F.Supp. 934 (D. D.C., 1954); Radio Pictures, Inc. v. Jarrico, 128 Cal. App.2d 172, 274 P.2d 928 (1954).

If such an employment contract expressly allows the employer to discharge an employee for exercising his privilege against self-incrimination, the contract would prima facie appear to bind an employee who as a contracting party specifically agreed to the provision, since a private employer is not controlled by the constitutional limitations which apply to public employers. A provision requiring an employee to relinquish a constitutional right as a condition of keeping his job, however, could be held unenforceable as contrary to public policy, particularly if applied to an individual employee not in a position to exercise complete freedom of choice as to the terms of his employment. Contractual provisions infringing constitutional rights have been held invalid on grounds of public policy. Gallagher v. American Legion, 154 N.Y.Misc. 281, 277 N.Y.Supp. 81 (S.Ct., 1934) ; Spayd v. Ringing Rock Lodge, $270 \mathrm{~Pa} .67,113$ Atl. 70 (1921). On the other hand, enforcement of the condition might be justified, as a matter of public policy, to protect the economic interests of an employer if he could show that the exercise of the privilege substantially interfered with the performance of the employee's duties or could prove the actual existence of an unfavorable public reaction, even if unreasonable, that adversely affected to a substantial degree the marketability of his product or the efficiency of his business operations.

Court enforcement of a private, contractual provision permitting discharge of an employee for exercising a constitutional right might also be construed as constituting infringement of that right by the state in violation of the state or federal constitutions. See Rice v. Sioux City Cemetery, 349 U.S. 70 (1955) ; Black v. Cutter Laboratories, supra, at 300-304 (dissent); Spayd v. Ringing Rock Lodge, supra; Horowitz, op. cit. supra note 101, at 272-73; Hale, op. cit. supra note 108, at 398-99. However, while the Supreme Court has held that enforcement by a court of a private, contractual provision having the effect of infringing the constitutional rights of other persons, not parties to the contract, is unconstitutional state action (Barrows v. Jackson, 346 U.S. 249 [1953]; Shelley v. Kraemer, 334 U.S. 1 [1948]); it has not yet held that enforcement by a court of a private, contractual provision limiting the free exercise of a constitutional right by a party to the contract, who had specifically agreed to the limitation, is unconstitutional state action as to such party. But see Rice v. Sioux City Cemetery, supra; Black v. Cutter Laboratories, supra, at 300-304 (dissent). But enforcement by a court of an agreement between employers not to hire any person who had asserted his constitutional privilege against self-incrimination might be unconstitutional state action as to a person deprived of employment as a result of the agreement. See Shelley v. Kraemer, supra; Barrows v. Jackson, supra. 